\title{
TYRANNY, WORK AND POLITICS: THE 1818 STRIKE WAVE IN THE ENGLISH COTTON DISTRICT*
}

Summary: Critics of E. P. Thompson have questioned his emphasis on the ties between radicalism and trade unionism in early nineteenth-century England; historians have likewise described the 1818 strikes as simple wage disputes in which the radicals played a negligible role. This essay challenges these assumptions about the 1818 strikes and radicalism. In the summer of 1818 , when a wide range of grievances touched off the strike wave, the radicals rallied to the side of the trades and sometimes served as leaders of the strikes; that summer the radicals and striking trades also drew upon and contributed to a shared repertoire of old and new tactics and forms of action.

On 1 September, near the end of the long, hot summer of 1818 , five hundred mule spinners marched from Manchester to Sandy Brow, in Stockport, where a crowd of several thousand had gathered for a meeting which marked the climax of the trade militancy and radicalism of that summer, a summer rife with rumors about plans for "a general insurrection of all the labouring classes". ${ }^{1}$ During the previous four months, almost a dozen trades had abandoned the workshops, pits, and factories of Manchester and its environs, and only three weeks before, over fifteen trades had joined together to form a general union of all trades, the Philanthropic Society, for "Trade and Reform". ${ }^{2}$ On that rainy afternoon at Sandy Brow, John Bagguley and Samuel Drummond, veterans of the radical campaign of

* I am indebted to Jim Epstein, Doug Flamming, and Mel McKiven for their valuable comments on earlier versions of this article. All dates cited refer to the year 1818 unless otherwise specified.

${ }^{1}$ Public Record Office [hereafter PRO], Home Office Papers [hereafter HO] 42/179 Ethelston to Sidmouth, 18 August. According to the Manchester Mercury, 4 August [hereafter $M M$ ] , the summer of 1818 was the warmest one since 1779 . There is a printed selection of Home Office papers on the 1818 strikes in A. Aspinall (ed.), The Early English Trade Unions: Documents from the Home Office Papers in the Public Record Office (London, 1949). J.L. and Barbara Hammond reprinted several 1818 trade addresses in their pioneering studies The Skilled Labourer, 1760-1832 (London, 1919; reprint edition, New York, 1967), and The Town Labourer, 1760-1832 (London, 1917; reprint edition, New York, 1967).

2 PRO, HO 42/179 "To all Colliers in Newton Duckinfield Hyde \& Stayley Bridge", from James Fielding, 7 August, enclosed in Lloyd to Hobhouse, 22 August; see also, Hammonds, Skilled Labourer, pp. 103-104. 
The cotton district in 1821

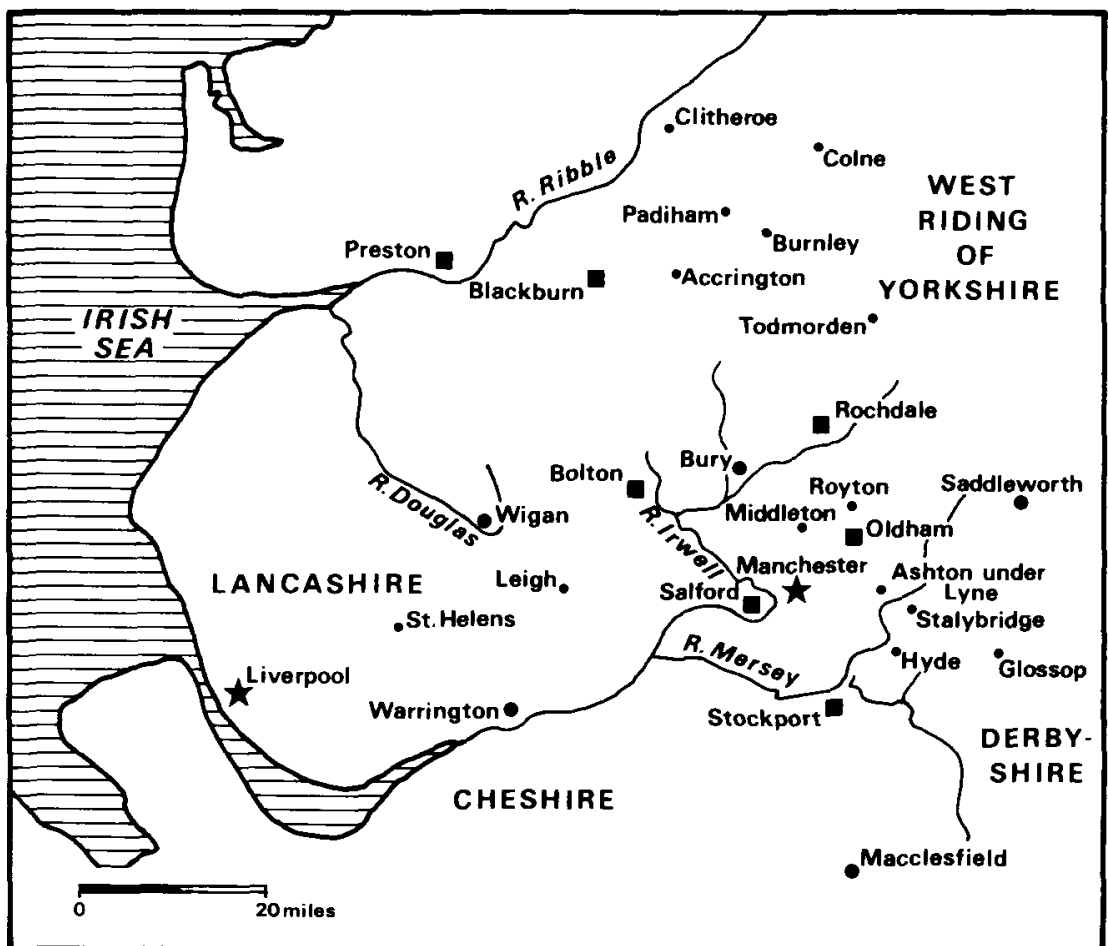

100,000 to 120,000 inhabitants

$\begin{array}{ll}\text { Liverpool } & 118,972 \\ \text { Manchester } & 108,016\end{array}$

20,000 to 32,000 inhabitants

Bolton

Rochdale

Salford

31,295

27,798

25,772

Preston

24,575

Blackburn

21,940

Stockport

21,726

Oldham

21,662

10,000 to 20,000 inhabitants

Macclesfield

Wigan

17,746

Saddleworth

Warrington

Bury
- under 10,000 inhabitants

Ashton-under-Lyne $\quad 9,222$

Colne

7,274

Burnley

6,378

Middleton

5,809

Leigh

5,190

Stalybridge

Todmorden

$\pm 5,000$

Royton

4,985

St. Helens

4,933

Glossop

Hyde

4,820

4,130

3,355

Clitheroe

3,213

Padiham

3,060

Accrington

Source: PP (Commons) 1822 [502]XV. 
1816-17, praised the striking spinners and weavers for their courageous resistance to the "tyranny" of their masters and likewise denounced the "tyrannical" government of Lord Liverpool. ${ }^{3}$

William Reddy and Charles Tilly have recently cautioned against judging these kinds of events, especially the turn outs of the early nineteenth century, by the standards of the twentieth-century world. Reddy, in his study of the French textile trade, has emphasized in particular the continued importance of "nonmarket factors" in the strikes of the nineteenth century. With a few recent exceptions, the historians who have examined the events of the summer of 1818 have paid little attention to what Reddy has referred to as "nonmarket grievances" and have instead portrayed the 1818 strikes as straightforward wage disputes. The artisans and factory workers who launched the strike wave of that summer certainly focused on the issue of wages in their official addresses and often pointed to the state of the market to strengthen their case for an advance; however, as E. P. Thompson has pointed out, the central concern of the 1818 address of " $\mathrm{A}$ Journeyman Cotton Spinner" was not the "bread-and-butter" issue of wages but rather "changes in the character of capitalist exploitation". ${ }^{4}$ For the trades that turned out that summer, from the spinners and handloom weavers to the hatters and coal miners, the strikes clearly went beyond dissatisfaction over wage cuts and high prices and instead turned on a

${ }^{3}$ Manchester Observer, 29 August [hereafter $M O$ ]; PRO, HO 42/180 Lloyd to Hobhouse, 3 September; Report of John Livesey; A Full, Accurate, and Impartial Report of the Trial of John Bagguley, of Stockport, John Johnston, of Salford, and Samuel Drummond, of Manchester (Manchester, 1819), pp. 20-35. I am grateful to Jim Epstein for the reference to the trial.

${ }^{4}$ William M. Reddy, The Rise of the Market Culture: the Textile Trade and French Society 1750-1900 (Cambridge, 1984), pp. 185-186, 225-226; Charles Tilly, The Contentious French (Cambridge, MA, 1986), pp. 3-5, 390-398, and E. P. Thompson, The Making of the English Working Class (Vintage edition, New York, 1966), pp. 202-203. For accounts of the 1818 strikes, see Hammonds, Skilled Labourer, pp. 94-121; R. G. Kirby and A. E. Musson, The Voice of the People: John Doherty, 1798-1854 Trade Unionist, Radical, and Factory Reformer (Manchester, 1975), pp. 18-27; John Mason, "Mule Spinner Societies and the Early Federations", in Alan Fowler and Terry Wyke (eds), The Barefoot Aristocrats: A History of the Amalgamated Association of Operative Cotton Spinners (Littleborough, 1987), pp. 19-23; H. A. Turner, Trade Union Growth, Structure, and Policy: A Comparative Study of the Cotton Unions in England (Toronto, 1962), pp. 67-69; Duncan Bythell, The Handloom Weavers: A Study in the English Cotton Industry during the Industrial Revolution (Cambridge, 1969), pp. 193-197, and Robert Glen, Urban Workers in the Early Industrial Revolution (London, 1984), pp. 70 $75,219-224$. For the 1818 strikes as "the first ever attempt at a general strike" and the radicals' involvement, see Mick Jenkins, The General Strike of 1842 (London, 1980), pp. 30-32; John Foster, Class Struggle and the Industrial Revolution: Early Industrial Capitalism in Three English Towns (London, 1974), pp. 101-102 and John Belchem, "Orator" Hunt: Henry Hunt and English Working-Class Radicalism (Oxford, 1985), p. 86. 
variety of grievances which ranged from bitter resentment over the "tyranny" of their masters and the recent defeat of Sir Robert Peel's factory bill to concerns about the artisan's loss of "independence" and moral views about an Englishman's right to what an Oldham weaver called "that fair reward for their labour, which both justice and humanity assign to them". ${ }^{5}$ In the summer of 1818 , striking factory workers and artisans, journeymen spinners and hatters alike, shared not only these common grievances but also the outlook and institutions of the "respectable" artisan, and it was these shared grievances and values which made possible the formation of the Philanthropic Society and its fleeting vision of a general union, "the Working Class of Society", to oppose "their avaricious Employers". 6

While E. P. Thompson's classic work, The Making of the English Working Class, has exerted a powerful influence in the debate over the emergence of the "Working Class of Society" in nineteenth-century England, a number of historians have challenged his account of the emergence of class consciousness in the 1830s and his emphasis on the links between radicalism and trade unionism in the early decades of the century. Several of his critics have in turn put forward what F. K. Donnelly has called the " "compartmentalist' interpretation of early English working-class history". Their response to Thompson's "holistic" interpretation of class and working-class protest has been to compartmentalize working-class grievances and aspirations into neatly segregated "political" and "industrial" categories. $\mathrm{Al}$ -

"MO,2 January 1819. For "independence" and the idea of a "fair" wage, see John Rule, "Artisan Attitudes: A Comparative Survey of Skilled Labour and Proletarianization Before 1848", Bulletin of the Society for the Study of Labour History, 50 (1985), pp. 25-26; Thompson, Making of the English Working Class, pp. 235-236, and E. J. Hobsbawm, "Custom, Wages, and Work-load in Nineteenth-Century Industry", in Labouring Men: Studies in the History of Labour (New York, 1964), pp. 348-349.

${ }^{6}$ PRO, HO 42/180 "At A Meeting of Deputies from the Undermentioned Trades", broadside. For a shorter version of the address and resolutions of the Philanthropic Society, see HO 42/179 “Manchester, August 19th, 1818”, broadside; see also, Aspinall, Early English Trade Unions, pp. 272-274. For "respectability" and skill as a form of property, see I. J. Prothero, Artisans and Politics in Early Nineteenth-Century London: John Gast and His Times (Folkestone, 1979), pp. 26-28, and John Rule, "The Property of Skill in the Period of Manufacture", in Patrick Joyce (ed.), The Historical Meanings of Work (Cambridge, 1987), pp. 102-113.

${ }^{7}$ Thompson, Making of the English Working Class, pp. 9-12, 483, 500, 577, 712, 807, 825-828. For examples of the "compartmentalist" approach see Bythell, Handloom Weavers, pp. 176-232; Glen, Urban Workers, pp. 92-93, 137-139, 192-193, 278-285, and A. E. Musson, British Trade Unions, 1800-1875 (London, 1972), pp. 19-20, 43-48. For criticism of the "compartmentalist" approach, see F. K. Donnelly, "Ideology and Early English Working-Class History: Edward Thompson and his Critics", Social History, 1 (May 1976), pp. 223-229, and Robert Sykes, "Early Chartism and Trade Unionism in South-East Lancashire", in James Epstein and Dorothy Thompson (eds), The Chartist Experience: Studies in Working-Class Radicalism and Culture, 1830-60 (London, 1982), pp. 152-154, 184-185. 
though Gareth Stedman Jones has approached the question of class from a very different perspective, he has likewise downplayed the radicals' support for trade unionism and for a wide range of working-class grievances and has instead emphasized the primacy of politics in radicalism and later in Chartism. He has also taken issue with those historians who have viewed radicalism as a "class" movement. For Stedman Jones, radicalism was, above all, "a vocabulary of political exclusion whatever the social character of those excluded". 8

In the summer of 1818 , the loyalties of the reformers, however, clearly rested with the "Working Class of Society". But, because this support was a reflection of the working-class character of Lancashire radicalism, the relationship between the trades and the radicals in 1818 inevitably consisted of more than a simple sense of loyalty. That summer radicals addressed meetings of striking hatters, weavers, and spinners and fiercely attacked the "tyrannical" power of the master spinners and manufacturers. In outlying towns and villages, like Ashton-under-Lyne and Oldham, they served as leaders of the local weavers' committees and raised the call for a general strike and a union of all trades. By their outspoken support for the trades, both from the hustings and in the press, and by their virulent attacks on Lord Liverpool's government, the radicals created an atmosphere of growing militancy and confrontation in the cotton district and focused attention on the connection between the misery and oppression of the working class and the selfish actions of the corrupt, unrepresentative government at Westminster. The weaver poet Samuel Bamford emphasized the power of this message in an often quoted observation about the popularity of William Cobbett's writings in Lancashire. "He directed his readers", recalled Bamford, "to the true cause of their sufferings - misgovernment; and to its proper corrective - parliamentary reform. Riots soon became scarce, and from that time they have never obtained their ancient vogue with labourers of this country." ${ }^{, 9}$ In early nineteenth-century Lancashire, this politicization

${ }^{8}$ Gareth Stedman Jones, "Rethinking Chartism", in Languages of Class: Studies in English Working Class History 1832-1982 (Cambridge, 1983), pp. 104-107. For criticism of this aspect of Stedman Jones' interpretation, see James Epstein, "Understanding the Cap of Liberty: Symbolic Practice and Social Conflict in Early Nineteenth-Century England", Past and Present, 122 (February 1989), pp. 75-77; Neville Kirk, "In Defence of Class: A Critique of Recent Revisionist Writing upon the Nineteenth-Century English Working Class", International Review of Social History, XXXII (1987), pp. 2-47, and Dorothy Thompson, "The Languages of Class", Bulletin of the Society for the Study of Labour History, 52 (1987), pp. 54-57.

${ }^{9}$ Samuel Bamford, Passages in the Life of a Radical (London, 1844; reprint edition, New York, 1967), p. 7. For similar views on the class nature of Lancashire radicalism, see $\mathbf{H}$. W. C. Davis, “Lancashire Reformers, 1816-17”, Bulletin of the John Rylands Library, X (1926), pp. 48-49; Thompson, Making of the English Working Class, pp. 294-295, 642-644, and Belchem, "Orator" Hunt, pp. 110-112. 
of popular attitudes about the causes of distress led to the decline of what John Bohstedt has called "the politics of food riot" and also ultimately encouraged the development of new forms of working-class protest. In the summer of 1818 , the radicals and striking trades both drew upon and contributed to this changing repertoire of old and new tactics and forms of action, a repertoire which included not only Hobsbawm's "collective bargaining by riot" but also the mass procession and the "constitutionalist reform demonstration". ${ }^{10}$

"With the restoration of the Habeas Corpus Act", Samuel Bamford recalled about 1818, "the agitation for reform was renewed." aspect of the radical revival in Lancashire was the appearance in early January of the first issue of what became one of the most widely read radical newspapers of its day, the Manchester Observer. In addition to devoting considerable space to reform issues, from parliamentary debates to reports of radical meetings and dinners in London and the provinces, the Manchester Observer also played a vital role in publicizing the ideas and activities of the local movement. It published notices and detailed accounts of local meetings as well as letters and addresses from working-class reformers, while constantly criticizing the corruption and misdeeds of the High Tory oligarchies both in Manchester and at Westminster. Although its editorial policy was to deny the radicals' involvement in the 1818 strikes, the paper nonetheless publicized the demands and grievances of the trades and supported the spinners during their lengthy strike, even after the riots and violence of early September. ${ }^{12}$ The Manchester Observer, however, was not the only radical paper to pay attention to Lancashire during the summer of 1818. Other radical journals, like Sherwin's Political Register and the Black Dwarf, supported the spinners and published letters and addresses on their behalf. ${ }^{13}$

${ }^{10}$ John Bohstedt, Riots and Community Politics in England and Wales 1790-1810 (Cambridge, MA, 1983), pp. 3-5, 91-93; Alan Booth, "Food Riots in the North-West of England 1790-1801", Past and Present, 77 (1977), pp. 104-107; John Dinwiddy, "Luddism and Politics in the Northern Counties", Social History, 4 (1979), pp. 35-51, 60-63; E. J. Hobsbawm, "The Machine Breakers", in Labouring Men, p. 7; Belchem, "Orator" Hunt, pp. 4-7, 58-70 and Thompson, Making of the English Working Class, pp. 679-681.

${ }^{11}$ Bamford, Passages, p. 164.

12 Donald Read, Peterloo: The "Massacre" and Its Background (Manchester, 1958; reprint edition, Manchester, 1973), pp. 55-56; $M O, 18$ July and 1 August; $M O, 16$ May (jenny spinners), 13 June (joiners), 20 June (hatters), 27 June (dyers), 15 August (handloom weavers), $18 \mathrm{July}, 1$ and 8 August, and 12 September (spinners).

${ }^{13}$ Sherwin's Political Register, 1, 8, 29 August [hereafter SPR]; Black Dwarf, 19 August, 
With the exception of the Manchester Observer and the public forum which its columns provided, the most important means of publicizing the radical program and organizing the movement was the open-air meeting, a popular and innovative feature of the 1816-17 campaign in Lancashire. In early 1817, the Manchester Political Register enthusiastically endorsed this new practice as a means of disseminating news and information about the movement and of demonstrating "that unanimity of sentiment and feeling" and also emphasized how the public meeting contributed to "the peace of society" by directing the people's attention to "the real causes of their calamity":

In former periods, when the sufferings and distresses of the people bore no proportion to those which are now endured, mobbing and rioting were resorted to as the best if not the only remedy for their complaints. Now, however, the very lowest in the scale of society are instructed in the real causes of their calamity, and in the best remedy for it. Now, they see a legal and peaceable mode of procedure, which is calculated to produce, not merely temporary, but permanent relief; and hence their patient and exemplary behavior. ${ }^{14}$

Apart from the informal gathering at the local inn and the occasional radical reading society or debating room, the hustings and the open-air meeting were the central features of the radical campaign in early 1818 ; it was primarily a year of agitation, not formal organization. ${ }^{15}$ During the roughly six months between 9 March, when the first meeting was held, and the climactic meeting of 1 September at Stockport, at least sixteen parliamentary reform meetings took place in the greater Manchester area. Over a dozen towns and villages in the cotton district held meetings during this period, and the demonstrations ranged in size from around one thousand to the five to nine thousand at Stockport on 1 September.$^{16}$ The main speakers at these meetings read like a roll call of the local leadership in 1816-17; they included two of the key figures in the Blanketeers' March, Samuel Drum-

9 and 30 September [hereafter $B D$ ]; Cobbett's Weekly Political Register, 19 December; see also, Gorgon, 1 and 15 August, 5 and 12 September 1818; 9 and 23 January, 6 and 27 February 1819.

${ }^{14}$ Manchester Political Register, 4 January 1817. Thompson, Making of the English Working Class, pp. 679-681.

${ }^{15} M O, 18$ and 25 April; Nicholas Cotton, "Popular Movements in Ashton-under-Lyne and Stalybridge Before 1832" (M.Litt, thesis, University of Birmingham, 1977), p. 109, and PRO, HO 42/174 Lloyd to Hobhouse, 12 February.

${ }^{16}$ Meetings were held at Manchester, Royton, Oldham, Stockport, Lees, Pilkington, Middleton, Saddleworth, Ashton-under-Lyne, Birch, Mossley, Heywood, Failsworth and Rochdale. For reports of these meetings, see PRO, HO 42/175-180 and published accounts of speeches and resolutions in the Manchester Observer, Black Dwarf, and Sherwin's Political Register. For attendance figures, see PRO, HO 42/175 Lloyd to Hobhouse, 9 March; HO 42/178 No. 2 to Byng, 14 July; Bamford, Passages, p. 167; HO 42/180 Report of John Livesey, and A Full, Accurate, and Impartial Report, pp. 20, 30. 
mond and John Bagguley, as well as "revered and ruptured" William Ogden, John Johnston, Samuel Bamford, William Benbow, and Robert Pilkington (see Table 1).

Table 1

Occupations of speakers and chairmen at reform meetings ( 9 March to 1 September 1818)

\begin{tabular}{|c|c|c|c|}
\hline Occupation & $\mathbf{N}$ & Occupation & $\mathbf{N}$ \\
\hline $\begin{array}{l}\text { Nonconformist minister } \\
\text { and schoolmaster }\end{array}$ & 1 & $\begin{array}{l}\text { Weavers } \\
\quad \text { (cotton, woollen, silk) }\end{array}$ & 11 \\
\hline Schoolmaster & 1 & Tailors & 2 \\
\hline Small manufacturers & 3 & Shoemakers & 2 \\
\hline "Doctors" & 2 & Clogger & 1 \\
\hline Small tradesman & 1 & Hatter & 1 \\
\hline Bookseller & 1 & Stonecutter & 1 \\
\hline Printers & 2 & Reedmaker & 1 \\
\hline Newsagents and vendors & 2 & Joiner & 1 \\
\hline
\end{tabular}

Source: PRO, HO 42/175-180.

Although the local leadership in 1818 included a number of master manufacturers and tradesmen, the majority of the radical leaders came from the workshops and weavers' cottages of Lancashire and Cheshire. In the small towns and weaving hamlets of the cotton district, the cause of reform was closely identified with the working class. "They were", noted a spy report about the crowd at Royton, "all of the working Class with the Exception of a few Royton people amongst whom there were a few of the Rank next above the working Class viz small manufacturer and master Craftsmen. ${ }^{17}$ E. P. Thompson has in fact described Lancashire radicalism during the years 1816-20 as "a movement of weavers" and has argued that the old-fashioned radicalism of Cobbett and Hunt "did not speak for the factory workers' predicament". ${ }^{18}$ At first glance, the profile of the occupations of the local speakers and chairmen tends to support his claim. Weavers represented the single largest occupational group, making up one-third of the speakers. On the other hand, factory workers, especially the mule spinners, were conspicuous in their absence. The lack of radical leaders from the ranks of the spinners, however, hardly meant that they were unsympathetic towards parliamentary reform. Long hours of work and the ever present threat of dismissal and the blacklist made leadership both difficult and risky for the spinners; but, as the 1816-17 campaign demon-

${ }^{17}$ PRO, HO 42/175 Chippendale to Fletcher, 23 March. See also, HO 42/176 Chippendale to Fletcher, 20 April, and HO 42/178 Report of John Livesey, 6 July.

18 Thompson, Making of the English Working Class, pp. 294-295, 644-645. 
strated, there was a considerable base of support among the factory workers for the radical program. On several occasions, the radicals charged that certain "tyrannic" mill owners had fired workers for attending meetings. In a cover letter to a spy report of a debate at the Manchester Constitutional Society, the boroughreeve and constables stated: "These Meetings are swelled much in numbers from the moment the Spinning Factories in the neighbourhood leave off working - a proof that the discontent is not confined to those who are distressed, the circumstances of the Spinners being comparatively good." 19 Several informers also reported that the spinners had contributed twenty pounds from their friendly societies to the Blanketeers. ${ }^{20}$

For James Norris and the other magistrates, the most disturbing aspect of these meetings was the speakers' savage, frequently highly personal attacks on Lord Liverpool's government and the masters. Norris even accused the radicals of seeking to promote "the idea of a general rising". Although this charge overstated the dangers of the situation in Lancashire, it was not pure fantasy. Several of the most active local reformers, such as Bagguley and Johnston, openly condemned the idea of another petition campaign and advocated instead various confrontational tactics which included defensive arming, the calling of a national convention, the withholding of taxes, and a march to London. ${ }^{21}$ The speeches and resolutions of these meetings furthermore took the form of an aggressive critique of "this Abominable and Tyranacall system of government" and vigorously attacked the recent suspension of habeas corpus, the passing of the Corn Bill, high taxes, and the swollen national debt. ${ }^{22}$ At a series of meetings during the strike wave of that summer, local reformers likewise frequently denounced the mill owners and manufacturers as "tyrants" and oppressors and urged the men to resist, as William Fitton said, "the Tyranny of their masters". In London, at the Palace Yard meeting, which took place near the climax of the "simultaneous movement" in the cotton district, Henry Hunt likewise rallied to the side of the striking trades and defended the spinners' right to a fair wage:

${ }^{19}$ PRO, HO 40/4 Cover letter of the Boroughreeve and Constables of Manchester, February 1817, quoted by Davis, "Lancashire Reformers", p. 74. HO 40/9(1) Pamphlet on 28 October 1816 meeting in Manchester; Manchester Political Register, 15 February 1817; see also, HO 42/198 Norris to Sidmouth, 2 November 1819.

${ }^{20}$ PRO, HO 42/161 Wild to Duckworth, 13 March 1817, and HO 40/5(4a) Deposition of John Livesey, 8 March 1817.

${ }^{21}$ PRO, HO 42/178 Norris to Sidmouth, $29 \mathrm{July}$; A Full, Accurate, and Impartial Report, pp. 20-35; HO 42/177 Brother to No. 2 to Chippendale, 26 April and 17 May; $S P R, 6$ June and $25 \mathrm{July}$, and Bamford, Passages, pp. 167-168.

22 PRO, HO 42/177 Brother to No. 2 to Chippendale, 17 May; for detailed reports of the speeches at these meetings, see spy reports and depositions in $\mathrm{HO} 42 / 175-180$; see also, for resolutions of meetings at Manchester, Lees, Mossley, and Ashton, MO, 14 March, 2 May and $11 \mathrm{July}$; $S P R, 6$ June. 
They sought only for an equitable proportion of the profits resulting from the manufactory which their labour produced. They sought that to which every industrious labourer was entitled - namely, that he should be able to maintain himself and his family, and lay by something for a wet day. This was the right of an Englishman, and he should never cease to struggle until that right was attained. ${ }^{23}$

Although some of the radicals, like Bagguley and a group of Oldham and Ashton firebrands, spoke out in favor of the short time bill and "the Union of Trades", the Lancashire reformers generally argued that the ultimate solution to the problems of high prices and depressed piece rates was to break the "tyrannical" power of the corrupt, unrepresentative House of Commons through their reform program of universal suffrage and annual parliaments. "The people can expect", charged Fitton, "no favour from such men as Castlereagh, Sidmouth, Canning, and Liverpool, Men of the most diabolical principles, who have robbed you of the fruits of your industry, of your liberty, and independency, and reduced you to abject slavery."24 At Saddleworth Bagguley pointed to the borough mongering system as the cause of "the calamitious distress" of the kingdom and went on to emphasize, "if the people had been fairly and constitutionally represented this dreadful calamity would not have happened". ${ }^{25}$ The national debt and the "ruinous system of paper money", the parasitic host of placemen and pensioners, the heavy burden of indirect taxation, "a taxation that carries off the industry of the people through a thousand channels", were all products of "this abominable system", and for Bagguley and the other radicals, the only solution to poverty, "the constant companion of despotism", was to put an end to the monopoly on political power and "Partial Legislation" through parliamentary reform. ${ }^{26}$ In the context of the high prices and wage cuts of the postwar years, when the Corn Laws protected the price levels of grain and the Combination Acts and the repeal of statutory apprenticeship posed very real threats to the "respectable" artisan, this analysis of the political origins of low wages and distress had considerable power. In a passage on the Combination Acts, in his letter to the Manchester spinners, William Cobbett gave a classic statement of the

${ }^{23} M O, 12$ September. PRO, HO 42/178 No. 2 to Byng, 14 July; HO 42/179 Brother to No. 2 to Chippendale, 21 July, and $A$ Full, Accurate, and Impartial Report, pp. 23, 27, $29,31-32$.

${ }^{24}$ PRO, HO 42/177 Report of Brother of No. 2, 10 May. HO 42/178 "A Public Meeting of the Friends of the Short Time-Bill", handbill; for the Oldham and Ashton radicals, see HO 42/179 Chippendale to Fletcher, 11 August; Brother to No. 2 to Chippendale, 21 and 27 July.

${ }^{25}$ PRO, HO 42/177 Report of Brother of No. 2, 10 May.

${ }^{26} M O, 25$ April (Oldham); 2 May (Lees); 14 March (Manchester); see also, BD, 20 May (Middleton), and $S P R, 6$ June (Ashton). 
radicals' views about the social and economic effects of the "tyrannical" power of "Old Corruption":

Do you think, that such an Act would have been passed, if the Journeymen of England had had a vote at elections? This, therefore, clearly shews, how your miseries and degradation arise from the want of a Reform. Your "Masters," as they have the insolence to call themselves, know this too; and therefore, they do all that lies in their power to uphold the present system. This is one of the reasons, why they are opposed to Reform. Without Justices of the Peace with powers of Judge and Jury, and without shooters in redcoats to come at the call of those Justices, they know well that you would have from them the worth of your labour. ${ }^{27}$

During the winter months of 1818 , when the cotton spinners renewed the short time campaign, they encountered yet another example of the consequences of "the want of a Reform". "Your Petitioners", they wrote, "who have for the last two years cherished the expectation of relief from the Legislature, cannot adequately express the concern they felt in learning upon the conclusion of the last session, that no provisions had then been made for this purpose." 28 Apart from the efforts of Nathaniel Gould, a wealthy merchant and philanthropist, to organize support for Peel's bill, the main impetus behind the revival of the short time movement in the cotton district came from the spinners, especially the Manchester fine spinners. ${ }^{29}$ They took the lead in organizing the petition campaign in support of Peel's bill and in supplying Peel and his parliamentary allies, like William Smith, with information on factory conditions. ${ }^{30}$ John Brough,

${ }^{27}$ Cobbett's Weekly Political Register, 19 December. See also, SPR, 28 November.

${ }^{28} M O, 21$ February. Hansard's Parliamentary Debates, First series, XXXVII (1818), pp. 264-268, 559-566 [hereafter HD] and J. T. Ward, The Factory Movement 1830-1855 (London, 1962), pp. 24-27. Peel's bill limited children under sixteen to eleven hours and prohibited labour under the age of nine. The bill passed the House of Commons. But, on 10 June, when the parliamentary session came to a close, it still had not passed the House of Lords.

${ }_{29}$ Alfred [Samuel H. G. Kydd], The History of the Factory Movement, 2 vols (London, 1857; reprint edition, New York, 1966), 1, pp. 61-64; [Nathaniel Gould, and others], Information Concerning the State of Children Employed in Cotton Factories, Printed for the Use of the Members of Both Houses of Parliament (Manchester, 1818). For the mule spinners' role in the short time movement, see Parliamentary Papers (Commons) 1840 [504] X, pp. 1, 12 [hereafter PP]; PP (Commons) 1837-38 [488] VIII, p. 256; PP (Commons) 1833 [450] XX D1, p. 1; see also, Kirby and Musson, Voice of the People, pp. 346-348, and Philip Grant, The History of Factory Legislation: The Ten Hours' Bill (Manchester, 1866), pp. 14, 22.

${ }^{30}$ Spinners and factory workers from Manchester, Stockport, Ashton, Stalybridge, Bolton, Royton, and Glossop sent petitions in support of Peel's bill; see $H D$, First series, XXXVII (1818), pp. 1182, 1188-1189, 1259-1263; PP (Lords) 1818 [90] XCVI, pp. 3-5, 44. For the spinners' London delegation, see PRO, HO $42 / 179$ Examination of John Ollis, 29 August; PP (Lords) 1819 [24] CX, pp. 118, 203-204, and $H D$, First series, XXXVII (1818), pp. 264-268. 
leader of the pickets during the spinners' strike, collected signatures for short time petitions and gathered evidence on working conditions. Another leader during the strike, the roving delegate John Ollis spent several months in London as part of the spinners' delegation and later toured Lancashire after the close of parliament to give the spinners an account of the bill's prospects. By June, when Ollis was in the midst of his tour, the prevailing mood in Manchester was one of growing impatience and militancy. At Benjamin Gray's mill, the spinners bluntly told the manager: "The hours were not likely to be shortened, and that they would not derive those comforts from the Bill that were held out to them, and that therefore they must act for themselves." 31

With a few exceptions, like Joseph Brotherton, the master spinners of Manchester stood united in their condemnation of Peel's bill. ${ }^{32}$ On 16 February Lord Stanley presented a petition from a group of Manchester mill owners in which the petitioners were highly critical of the 1816 committee's investigation of child labour. In a later petition the master spinners requested an opportunity to present evidence to demonstrate the good health of their work force and "the injurious consequences" of the bill for the cotton trade; $; 3$ in fact, a committee of cotton spinners, under the leadership of Mr. Douglas, a Manchester merchant, had already engaged several local physicians and surgeons to inspect Manchester Sunday School scholars and to examine working conditions at a select group of spinning mills. Soon afterwards several of these medical practitioners appeared before Lord Kenyon's committee, where they gave evidence against Peel's bill and in general emphasized the salubrious effects of the fifteen hour day. ${ }^{34}$

Looking back at the tumultuous year of 1818 , the Manchester mill owners cited the short time movement as the primary cause of the spinners' strike. Norris reported in January 1819: "Great \& I think not unfounded apprehension of some mischief again occurring is entertained by the master spinners from the manner in which Mr. Gould is again moving amongst the operatives the question of time \&c. They believe that this was the main origin of the late turnout \& that if again agitated the same result is SURE to

${ }^{31} P P$ (Lords) 1819 [24] CX, pp. 434, 430-431. PRO, HO 42/179 Examination of John Ollis, 29 August.

${ }^{32} H D$, Third series, XXXIII (1836), p. 756.

${ }^{33} H D$, First series, XXXVII (1818), pp. 440-441; Ibid., XXXVIII (1818), pp. 578-579. The master spinners of Manchester, Stockport, Preston, Blackburn, and Rossendale petitioned against Peel's bill; see, Ibid., XXXVII (1818), pp. 1188-1189; and PP (Lords) 1818 [90] XCVI, pp. 3, 15.

${ }^{34}$ Ibid., pp. 6, 14, 25, 36-37, 41, 47-48, 85-86, 92-95, 108, 119-120, 124, 137, 224; see also, Ward, Factory Movement, p. 25. Several spinners who challenged these findings and the methods of the masters' committee were dismissed and blacklisted. PP (Lords) 1819 [24] CX, pp. 118, 203-204, 209-210, 430-434. 
follow: this is an uniform opinion amongst them." 35 The timing of the short time campaign obviously played a role in creating these suspicions. Its beginning coincided with a round of negotiations between the cotton masters and the operative spinners over restoring a wage cut; about a month after the close of the unsuccessful campaign for Peel's bill, the mule spinners, whose leaders included several men active in campaign, turned out. The arguments of those who opposed the bill also provided several clues to the master spinners' hostility towards factory reform. While trotting out familiar arguments against interference with free labour and parental rights and pointing to the bill's likely effects on profit margins, an anonymous opponent of the bill dwelt at length on the bill's detrimental effect on labour relations. Peel's bill, he emphasized, would destroy the connection between masters and men, and by reducing hours and thus wages, it would lead to the spread of a "mutinous spirit" and consequently to frequent strikes. Above all, he argued, the bill would cause the operatives to see themselves as the exploited victims of a "tyrannical" system:

The bill teaches them to look upon themselves as injured men, and their employers as avaricious oppressors; to regard their period of labour as a sacrifice of all they should value extorted from them by a selfish and unfeeling master, who exercises over them a more tyrannical control than any to which their equals in other trades are subjected. The inevitable consequence of all this is, that they will become discontented, and repining, and mutinous. ${ }^{36}$

It was against this background of confrontation between the mill owners and spinners over Peel's bill and open-air meetings for parliamentary reform that the strikes of 1818 began. Over a period of about ten weeks, between mid-May and mid-July, almost half a dozen trades turned out. In mid-May eight hundred Stockport jenny spinners, "a part of whom work in factories, and part not", turned out to restore the piece rate to the 1814 level of three pence a pound and to reduce their hours. Six weeks later they agreed to a compromise and returned to work at two and a half pence a pound. ${ }^{37}$ In early June, during the seasonal boom in the building trades, dissatisfaction over the "oppressed" state of their trades led to short, successful strikes by the Manchester bricklayers and the carpenters and

${ }^{35}$ PRO, HO 42/183 Norris to Sidmouth, 16 January 1819.

${ }^{36}$ An INQUIRY Into the Principle and Tendency of the Bill now Pending in Parliament, for Imposing Certain Restrictions on Cotton Factories (London, 1818), pp. 42-48, 50-56. For a similar attack on Peel's bill, see the speech of George Philips, HD, First series, XXXVIII (1818), pp. 364-365.

${ }^{37} P P$ (Lords) 1819 [24] CX, p. 369, and PP (Commons) 1824 [51] V, pp. 411-413. 
joiners. ${ }^{38}$ Just as these turn outs came to a close, the Manchester dyers launched their strike; it lasted only about two to three weeks and likewise succeeded in gaining the desired increase ${ }^{39}$ In early June similar grievances among the hatters, a numerous and well-organized trade in the Manchester area, came to a head. At a meeting in Denton, journeymen from surrounding towns and villages called on the hatting manufacturers to grant an advance and to establish a minimum price for hatting in the region. Several weeks later, hatters gathered at Oldham and Middleton, where "Reform orators" conducted the business of the meetings. Although most of the masters in the crucial hatmaking center of Denton agreed to meet the journeymen's demands, hatting manufacturers elsewhere refused, and in July the journeymen staged a brief, successful turn out to raise prices. ${ }^{40}$

On the surface the main object of these strikes was to obtain what the trades typically called "an advance in wages", but even this straightforward demand encompassed not only the matter of wages but also the craft pride and values of the "respectable" artisan. In their address, "To the Master Jenny Spinners of Stockport", the jenny spinners justified their demand for an advance by emphasizing their worth to society and their value as producers. They reminded their masters: "That our labour has been essential to the production of your wealth, and that we cannot, without remonstrance, at least, suffer ourselves, like bees, to be smothered in the hive which our exertions have so essentially contributed to fill." 41 The journeymen hatters likewise linked their demand for "a reasonable advance" to the need to establish "a minimum or lowest price for work" and to their opposition to the practice of putting out shoddy materials. The journeymen also claimed that the depressed state of their wages ultimately resulted in inferior workmanship and products and forced "the most industrious hatter" to seek parish relief, "a resource the most distressing to an honest industrious Englishman". ${ }^{42}$

Shortly after the conclusion of the jenny spinners' dispute in early July, the powerloom weavers of Stockport turned out in what was probably the

${ }^{38} M O, 13$ June; PRO, HO 42/178 Norris to Sidmouth, 29 July; for seasonality in the Manchester building trades, see Manchester Guardian, 14 May 1836.

${ }^{39} M O, 27$ June and $18 \mathrm{July}$; Manchester Gazette, 18 July [hereafter $M G$ ], and PRO, HO $42 / 178$ Norris to Sidmouth, 29 July.

${ }^{40}$ P. M. Giles, "The Felt-Hatting Industry, c. 1500-1850 with Particular Reference to Lancashire and Cheshire", Transactions of the Lancashire and Cheshire Antiquarian Society, 69 (1959), pp. 118-126; MO, 20 June; PRO, HO 42/178 XY to Byng, 16 July; Byng to Hobhouse, 18 July and Manchester Central Library, William Rowbottom diaries (microfilm copy), July 1818. For the continued importance of the equalization of prices for the journeymen hatters of Lancashire and Cheshire, see Manchester Guardian, 13 April 1822; Northern Star, 10 February 1844.

41 MO, 16 May.

42 Ibid., 20 June. 
first major strike by their trade. Unlike the other trades which took part in the first wave of strikes, the powerloom weavers were strictly factory workers, and their occupation was also a relatively new one. In Stockport and vicinity, one of the early centers of weaving by power, powerloom manufacture had its beginnings during the first decade of the nineteenth century and in 1818 probably employed only a few hundred, or at most, a thousand weavers, mainly adolescents and young women. ${ }^{43}$ At this point, when both the technology and organization of the new industry were still in the early stages of development, weaving by power still had strong ties to the domestic system of handloom weaving. Just as many of the men and women who made up the first generation of "steam" weavers were exhandloom weavers, the first generation of powerloom manufacturers included a number of former handloom manufacturers. ${ }^{44}$ Powerloom weavers, like handloom weavers, worked under a piece rate system and were subject to a variety of fines, a source of much ill will between the weavers and their masters under both systems. The early generations of master manufacturers likewise held fast to the old habit of cutting piece rates at the first hint of bad times. ${ }^{45}$ The weavers' opposition to several of these old practices formed the immediate background to the events of that summer. In addition to a recent dispute with their masters over the introduction of a fine system for the use of artificial light, an expense which handloom manufacturers traditionally passed on to the weaver, the powerloom weavers raised the familiar issue of low wages and demanded an increase which the magistrates described with exasperation as "a price equal to an advance of $50 \%$ ". When negotiations with the masters failed, the weavers launched what the Stockport authorities called "a general turn-out for more wages". ${ }^{46}$

From the very beginning of their strike, the powerloom weavers employed a variety of aggressive tactics; they doused strikebreakers at the

${ }^{43}$ Edmund Potter, Calico Printing as an Art Manufacture (London, 1852), pp. 10, 21; Richard Guest, A Compendious History of the Cotton Manufacture (Manchester, 1823; reprint edition, New York, 1968), pp. 46-47; PP (Commons) 1808 [179] II, pp. 5-9; see also, Glen, Urban Workers, pp. 35-37, 145. For the age and sex of the early work force in the Stockport area, see $P P$ (Commons) 1831-32 [706] XV, pp. 433-434; PP (Commons) 1824 [51] V, pp. $302,306$.

${ }^{4}$ Ibid., p. 421; PP (Commons) 1833 [690] VI, p. 677; Bythell, Handloom Weavers, pp. 258-259; Glen, Urban Workers, pp. 32-33, 145; see also, John S. Lyons, "Vertical Integration in the British Cotton Industry, 1825-1850: A Revision", Journal of Economic History, XLV (June, 1985), pp. 419-425.

${ }^{45} P P$ (Commons) 1833 [450] XX D2, p. 128; PP (Commons) 1842 [471] IX, pp. 37-38, 42, 47; Bythell, Handloom Weavers, pp. 119-120, and Richard Marsden, Cotton Weaving: Its Development, Principles, and Practice (Manchester, 1895), p. 495.

${ }^{46} P P$ (Commons) 1824 [51] V, p. 418; PP (Commons) 1808 [277] II, pp. 21-22, and PRO, HO 42/178 Prescot et al. to Sidmouth, 16 July. During the powerloom weavers' strike, the dressers, a group of workers who prepared the warp for the loom, also turned out. See HO 42/179 Lloyd to Hobhouse, 12 and 22 August. 
water pump, a method of punishment which loyalists had used against the radicals, and turned to riot and intimidation in the case of Thomas Garside's factory. ${ }^{47} \mathrm{~A}$ master spinner and manufacturer, Garside had rejected his weavers' request for an advance "with contumely" and then had proceeded to hire new workers from Burton-on-Trent and to pay them the advanced price as well. Infuriated by this move, the weavers made his factory the main focus of their struggle.$^{48}$ On three consecutive nights, from 14 to 16 July, the striking weavers and hundreds of others gathered at Garside's factory, singing "inflammatory" songs with a blind fiddler as accompanist and hurling abuse and threats, as well as stones and mud, at Garside and the new workers. On Wednesday evening, 15 July, the night of the worst rioting, Robert Harrison, a local magistrate, arrived on the scene with a number of constables and members of the Stockport cavalry; after reading the Riot Act, he launched into an attack on the radicals and warned the people to avoid the reformers and "the doctrines of such wicked incendiaries". The crowd responded with a volley of stones and brickbats, and Harrison and the yeomanry retreated in confusion. About midnight, after smashing the windows of the house where the new workers were lodged and threatening to tear down the mill, the people dispersed. ${ }^{49}$

These riots and the heavy-handed response of the local authorities, especially the firing of shots into the house of the prominent local reformer Thomas Cheetham and the fatal beating of the pauper William Reek, remained hotly debated issues over the next few weeks. ${ }^{50}$ In a series of letters to the Manchester Observer, the radical leaders Bagguley and Drummond defended the weavers and charged that the local authorities had used excessive force in suppressing the July riots; on 10 August Bagguley spoke at a meeting at Sandy Brow, where almost a thousand assembled to protest the "late outrages". The meeting condemned the authorities' actions as "the effects of despotism" and resolved to raise a subscription for the victims. ${ }^{51}$ The controversy, however, outlived the strike itself. In early August John Lloyd reported that the lack of funds and the masters' unified stand had led to a general drift back to work. By mid-August the first major strike of the powerloom weavers had ended in defeat. ${ }^{52}$

${ }^{47}$ Malcolm I. Thomis and Jennifer Grimmett, Women in Protest 1800-1850 (London, 1982), pp. 69, 73-74, and $M O, 25$ November 1820.

48 Ibid., 25 July; Wheeler's Manchester Chronicle, 12 September [hereafter WMC]; PRO, HO 42/178 Prescot et al. to Sidmouth, 16 July; Lloyd to Hobhouse, 19 July.

${ }^{49} W M C, 12$ September, PRO, HO 42/178 Prescot et al. to Sidmouth, 16 July; MO, 25 July, and Glen, Urban Workers, pp. 73-74.

so $M O, 25$ July and 15 August; $A$ Full, Accurate, and Impartial Report, pp. 57-62, and Glen, Urban Workers, pp. 219-220.

51 $M O, 25$ July, 8 and 15 August; for the 10 August meeting, see Glen, Urban Workers, pp. 220, and $M O, 22$ and 29 August.

${ }_{52}$ PRO, HO 42/178 Lloyd to Hobhouse, 23 and 25 July; HO 42/179 Lloyd to Hobhouse, 8 and 10 August, and Glen, Urban Workers, p. 74. 
The initial strike wave of May to early July consisted of a series of turn outs in half a dozen trades which ranged from traditional artisans, like the hatters, to the jenny spinners, "part of whom work in factories, and part not", to the new factory occupation of powerloom weaving; the issue at stake in all of these turn outs was on the surface wages, although other issues, like shorter hours and unpopular fine systems, came into play. The great strike of the Manchester cotton spinners, the climax of the summer of 1818 , demonstrated not only some of the difficulties in drawing a clear distinction between artisan and factory worker in the early nineteenth century but also the complexities of the wage question in the summer of $1818 .{ }^{53}$ Beginning in the 1780 s and lasting into the next century, a stream of hatters, shoemakers, smiths, tailors, and other journeymen left their trades for the high wages of mule spinning and brought with them into the factory the customs, like St. Monday and the "footing", and the institutions of the skilled trades. ${ }^{54}$ While the spinners never developed a formal apprenticeship system or a tramping network, two of the classic artisan institutions, they were able to use their role as subcontractors of labour to exercise control over entry into the trade, the grand object of formal apprenticeship, and on occasion took out a tramping card from one of the friendly societies; the friendly society also protected the spinner and his family against the hardships arising from accident, illness, and old age and frequently served as a kind of trade club, especially during the years before the repeal of the Combination Acts. ${ }^{55}$ But, above all, the spinners possessed the most important attribute of an artisan - skill. Their status as craftsmen was a product of the nature of work in the spinning rooms, where their skill, knowledge, and strength formed the basis of the labour process. ${ }^{56}$ The physical strength and

${ }^{53}$ During July and August, the Stockport and Wigan spinners also turned out. Glen, Urban Workers, pp. 72-75; PRO, HO 42/178 Lyon to Freeling, 20 July, and HO 42/179 Fletcher to Hobhouse, 8 August.

54 John Kennedy, "A Brief Memoir of Samuel Crompton", Memoirs of the Literary and Philosophical Society of Manchester (1831), pp. 335-336, and PP (Commons) 1834 [167] XIX D1, p. 169. For "footings" and St. Monday, see Poor Man's Advocate, 21 January 1832; William Chadwick, Reminiscences of Mottram (reprint edition, Longdendale, 1972), p. 9; John Dunlop, Artificial Drinking Usages of North Britain (fourth edition, Greenock, 1836), pp. 5-10; PP (Lords) 1819 [24] CX, pp. 344, 348-349, 377; PP (Commons) 1833 [519] XXI D2, p. 36; Prothero, Artisans and Politics, pp. 28-40, and Michael Hanagan, "Artisan and Skilled Worker: The Problem of Definition", International Labor and Working-Class History, 12 (1977), pp. 28-31.

${ }_{55}$ PP (Commons) 1842 [158] XXXV, pp. 14-15; P. H. J. H. Gosden, The Friendly Societies in England, 1815-1875 (Manchester, 1961), pp. 76-77, 221-223, 9-11, 71, PP (Commons) 1824 [51] V, p. 610.

${ }^{56}$ For detailed descriptions of the role of skill in spinning on the hand mule, see $P P$ (Commons) 1837-38 [488] VIII, pp. 306-307, and James Montgomery, The Theory and Practice of Cotton Spinning; or the Carding and Spinning Master's Assistant (third edition, Glasgow, 1836), pp. 178-179. 
stamina which was required to "put up" the heavy spindle carriage also ensured that mule spinning was largely an adult male occupation, although certain large mills in 1818, like M'Connel and Kennedy, employed women and young boys on small mules. ${ }^{57}$ The usual method of payment for mule spinning, the piece rate system, reflected both the spinner's ambiguous position as a wage earner and his trade's origins in the cottages and workshops of late eighteenth-century Lancashire, where working by the piece was a common practice. Under the piecework system, the spinner was not paid directly for his labour or his time, but for a product, yarn. "So much weight of prepared cotton is delivered to him", a factory inspector noted in the early 1830 s, "and he has to return by a certain time in lieu of it a given weight of twist or yarn of a certain degree of fineness, and he is paid so much per pound for every pound that he so returns." ${ }^{8}$ Out of these earnings, the spinner in turn paid a straight wage to his two or more piecers and frequently had to pay for oil, banding, and candles as well. ${ }^{59}$

For the "Journeyman Cotton Spinner", the transition from hand-powered mule spinning in cottages and private rooms to steam-powered spinning in factories formed the immediate background to the 1818 strike. Looking back to the early days of the trade, he penned an idyllic description of mule spinning in the closing decades of the eighteenth century:

When the spinning of cotton was in its infancy, and before these terrible machines for superseding the necessity of human labour, called steam engines, came into use, there were a great number of what were [ . . . called little masters; men who with a small capital, could procure a few machines, and employ a few hands; men and boys (say to twenty or thirty) [. . .] the master spinner was enabled to stay at home and work, and attend to his workmen. The cotton was then always given out in its raw state, from the bale to the wives of spinners at home, where they beat and cleansed it ready for the spinners in the factory. By this they could earn eight, ten, or twelve shillings a week, and cook, and attend to their families.

With the coming of the steam engine and large-scale factory production, the world of the small master and the independent spinner was doomed. The most striking example of this change, he argued, was the growing distance between masters and men, who were now "two distinct classes of persons". Lashing out at these new employers, "the overgrown capitalists", he charged: "They are literally petty monarchs, absolute and despotic, in their own particular districts [. . . ] their whole time is occupied in contriving how

${ }^{57} P P$ (Commons) 1816 [397] III, p. 355; $P P$ (Lords) 1818 [90] XCVI, p. 186, and $P P$ (Lords) 1819 [24] CX, pp. 237, 342, 400, 436.

${ }^{58}$ PP (Commons) 1834 [167] XIX D1, p. 119e, and Reddy, Market Culture, pp. 55, 79-82, 161, 166, 295.

${ }^{59} M O, 8$ August and 12 September; Gorgon, 12 September, and $B D, 9$ September. 
to get the greatest quantity of work turned off with the least expence." As the "Journeyman Cotton Spinner" repeatedly emphasized, the triumph of "the lofty ones" reduced the spinners to "instruments" and "bondsmen". In the concluding words of his address, he went on to argue that the strike of that summer ultimately grew out of the degraded status of the spinners' craft: "One thing [. . .] you may depend upon, that the important question, whether the workmen shall be the slaves of the master-spinners, or whether they shall have fair wages and due consideration in the scale of society, will shortly be set at rest." 60

Although the moderate, carefully worded "Cotton Spinners' Address to the Public" shared a number of these concerns, it began by presenting, and then justifying, the spinners' case in classic market terms. In 1816, when the cotton trade was in the midst of a depression, the masters demanded "a reduction of ten hanks" but promised to restore the reduction when the market improved. "About 10 months since", the spinners went on to claim, "on comparing the price of cotton and yarn, we found that the markets would allow our employers to fulfil their promise." The general response of the master spinners, however, was to refuse to restore the wage cut outright. After months of sporadic, unproductive negotiations, the spinners gave notice and turned out in early July. The reduction and the unsuccessful negotiations obviously played important roles in the strike's origins; but, as the address itself also revealed, the spinners' grievances went beyond the wage question. Like the cotton spinners' petition in support of Peel's bill, the address dwelt at length on the long hours of "unremitting toil" and the hot, unhealthy atmosphere of the mills and pointed to the "cadaveous and decrepit forms" of the factory children. In the conclusion the cotton spinners linked their rights as freeborn Englishmen to their demand for a fair wage. "We solemnly declare", the address stated, "as men, as fathers, as loyal subjects, and well-wishers to a constitution the spirit and letter of which will not countenance any thing like slavery and oppression, that we cannot obtain with the greatest possible industry the common comforts and necessaries of life, at the present low prices."

In early July the magistrates paid little attention to these grievances. What impressed the local bench was the number of those involved in the strike. Norris estimated that on the first day over 10,000 men, women, and

${ }^{60}$ For copies of this letter, see $M O, 3$ October, and $B D, 30$ September. For similar attacks on the master spinners, see $M O, 18$ April; PRO, HO 42/178 "The Mule Spinners' Address to the Public", handbill; see also, Hammonds, Town Labourer, pp. 301-302. ${ }^{61}$ For copies of this address, see Annual Register, 1818 "Chronicle", pp. 100-102; Gorgon, 15 August; $B D, 9$ September; see also PRO, HO 42/179 "The Cotton Spinners Address To the Public!", broadside. For negotiations between masters and men, see also PP (Lords) 1819 [24] CX, pp. 344-347, and HO 42/179 Examinations of John Fowler, John Hague, Edward Johnson, 29 August. 
children turned out; in the ensuing days, most of the remaining spinners left the spinning rooms, thereby closing down the mills and increasing the number of idle workers in Manchester to as many as 24,000 to $30,000 .^{62}$ The authorities also viewed with concern a related development - the spinners' adoption of the daily practice of "assembling in large bodies of two and three thousand each and parading through some of the streets of the town". ${ }^{63}$ Beginning in early July, the mule spinners organized striking factory workers into mass processions and solemnly marched three and four abreast through the streets of Manchester, a tactic which the dyers also had employed:

Public processions of large bodies of dyers, including of course many boys and very young men, have paraded the streets, presenting an orderly, but distressing spectacle of unemployed numbers [ . . ]. On the same plan, combining the same undesirable effects, great bodies of spinners have also been marshalled, marching in solemn order through selected districts in the town. Of these, a great part are children; what is worse, females. ${ }^{64}$

By publicizing the spinners' demands in this peaceful but dramatic fashion, in the form of "an orderly, but distressing spectacle of unemployed numbers", the processions forcefully demonstrated the spinners' organized strength and mass support and underlined the justice of their cause. "The[y] marched By Piccadilly", noted one of Colonel Fletcher's spies, "on Tuesday and was $23^{1 /} / 2$ minets in going Bye if his Majests minesters cd see the people that day or Ether of the days since the[y] would have past Sir Robert Peels Bill those who should have apeared as men was Like Boys of fifteen or sixteen." ${ }^{65}$ Just as Lancashire radicals went to great lengths in 1819 to make the meeting at St. Peter's Field "a display of cleanliness, sobriety, and decorum", the spinners also tried to use the parades to illustrate their respectability and peaceful intentions as well as to maintain discipline and morale. ${ }^{66}$ The processions, however, clearly contained an element of intimidation. The sheer number of those out of work, Norris noted, "created no small degree of alarm" among the middle classes, and strikebreakers and unfriendly shopkeepers quickly discovered that the parades sometimes took the form of a kind of charivari. "They paraded the

62 PRO, HO 42/178 Norris to Sidmouth, 29 July; PP (Lords) 1819 [24] CX, pp. 344-347; HO 42/179 Examinations of Edward Johnson and John Fowler, 29 August. For estimates of the total number of men, women, and children in the cotton mills of Manchester and vicinity, see $P P$ (Commons) 1816 [397] III, pp. 337, 372; HD, First series, XXXVII (1818), p. 594; PP (Commons) 1824 [51], V, p. 575.

${ }^{63}$ PRO, HO 42/178 Norris to Sidmouth, 29 July.

${ }^{64} W M C, 11$ July.

${ }_{65}^{65}$ PRO, HO 42/178 B to Fletcher, 9 July.

${ }^{66}$ Bamford, Passages, pp. 176-177, and Thompson, Making of the English Working Class, pp. 678-680. 
streets in great numbers", recalled James Frost, "to the amount of several hundreds; hooting and shouting either at tradesmen, or at the people that were disposed to follow their employ." 67

Soon after the strike began, the spinners likewise adopted what Norris called "a system of intimidation", or pickets, a tactic of the spinners since the 1790 s. " 4 or 5000 ", he noted, "or perhaps one or two thousand assembling from different factories $\&$ at the hour of work, viz. 4 or $5[$. . .] in the morning go to a factory at the other end of the Town where they are not known and so carry off by force or intimidation though without any violent breach of peace the hands who might be disposed to go to work." ${ }^{68}$ Apart from the obvious goals of enforcing and expanding the strike, the pickets also involved, like the processions, a struggle over the "contested terrain" of Manchester's streets and public areas. ${ }^{69}$ Writing about Manchester of the early 1840 s, the young Frederick Engels was struck by the carefully defined boundaries which separated the commercial district of middle-class Manchester from the working-class districts:

The town itself is peculiarly built, so that a person may live in it for years, and go in and out daily without coming into contact with a working-people's quarter or even with workers, that is, so long as he confines himself to his business or to pleasure walks. This arises chiefly from the fact, that by unconscious tacit agreement, as well as with out-spoken conscious determination, the workingpeople's quarters are sharply separated from the sections of the city reserved for the middle-class. ${ }^{70}$

The striking spinners clearly used the processions as a means of invading and occupying these sections of middle-class Manchester. The spinners, and later the handloom weavers, always marched through the city center and "the principal streets of the town" and often passed by the Police Office, the Exchange, and "the Commercial Buildings", potent symbols of the power and wealth of Manchester and the cotton industry. The picket system, by its very nature, also raised the question of what constituted the public sphere, and the magistrates, spinners, and mill owners quickly found themselves in a three-cornered struggle over the correct answer. Bor-

${ }^{67} P P$ (Commons) 1824 [51] V, p. 575. PRO, HO 42/178 Norris to Sidmouth, 29 July; see also, Bohstedt, Riots and Community Politics, pp. 7-10.

${ }^{68}$ PRO, HO 42/178 Norris to Sidmouth, 29 July. See also, WMC, 18 July and 1 August; HO 42/179 Examination of Edward Johnson, 29 August; PP (Commons) 1824 [51] V, pp. 573-575, and Bohstedt, Riots and Community Politics, pp. 129-130.

${ }_{69}$ Susan G. Davis, Parades and Power: Street Theatre in Nineteenth-Century Philadelphia (Philadelphia, 1986), pp. 13-14; John Berger, "The Nature of Mass Demonstrations", New Society, 23 May 1968, and Jurgen Habermas, "The Public Sphere", New German Critique, 3 (1974), pp. 49-55.

${ }^{70}$ Frederick Engels, The Condition of the Working Class in England, Introduction by $\mathrm{E}$. J. Hobsbawm (London, 1892; reprint edition, London, 1984), pp. 78-79. 
oughreeve Withington observed about the spinners: "They seem to be very well organized and lurk about the different mills in small bodies. When the Civil Power appear they offer no violence to any person proceeding to their work but they continue standing in clusters at the streets end [. . . ]. If they are asked to disperse they answer they have a right to stand in the highway."71 Rejecting out of hand such claims, several mill owners vigorously challenged the spinners' pickets and tried in particular to prosecute their leaders under the Combination Acts. But, just as a Salford resident was angered by the authorities' unwillingness to suppress bear and badger baitings in the public streets, the mill owners were, on occasion, exasperated by the magistrates' refusal to prosecute the spinners' pickets. ${ }^{72}$ In some cases, the magistrates simply disagreed with the mill owners' interpretation of the law and refused to act on their evidence. "The magistrates", Norris explained about one such case, "did not consider the mere assembling of hands round a mill without any other accompanying act a sufficient evidence of intimidation under the 3rd or 4th clause of the Combination Act $[\ldots]$. Were they to use threats or offensive gesticulations or language it would undoubtedly be a case within the clause." 73

It was these salient features of the demonstrations and pickets of July, discipline and the lack of violence, which the authorities found particularly disturbing. "The peaceable demeanour", Major-General Byng observed, "of so many thousand unemployed men is not natural. Their regular meeting and again dispersing shews a system and organisation of their actions which has some appearance of previous tuition." 74 Byng's suspicions about the existence of "a system and organisation" were correct. In 1818 the spinners already had a tradition of trade unionism which stretched back to the 1790s. Although the Manchester spinners' union had not survived the collapse of the 1810 strike, they had maintained an informal system of organization through their friendly societies and later through short time committees. Negotiations over restoring the wage cut and the petition campaign for Peel's bill in turn ultimately led to the creation of a more formal system. ${ }^{75}$ The broad outlines of the spinners' underground organization emerged, however, only after the arrest of their committee in late August. The "shop", or factory, was the basic building block; each mill sent

${ }^{71}$ PRO, HO 42/179 Withington to Hobhouse, 14 August. For the processions' routes, see HO 42/178 Norris to Sidmouth, 29 July; HO 42/180 Norris to Clive, 1 September, and $W M C, 5$ September.

${ }^{72} M G$, 4 July; PRO, HO $42 / 179$ Gray to Sidmouth, 24 August; Gray to Irving, 27 August.

${ }^{73}$ PRO, HO 42/179 Norris to Hobhouse, 28 August.

${ }^{74}$ PRO, HO 42/178 Byng to Hobhouse, 26 July.

${ }^{75}$ Kirby and Musson, Voice of the People, pp. 13-15; The Quinquarticular System of Organization. To the Operative Spinners of Manchester and Salford (Manchester, 1834); $P P$ (Commons) 1824 [51] V, pp. 573-575,610, and $P P$ (Commons) 1840 [504] X, pp. 1, 12. 
two representatives to the general meetings of the trade. These delegates periodically elected from among their own number a standing committee of twelve, each member representing a different "shop" and sitting on the committee for about four weeks. In early July this committee, which operated under the guise of a friendly society, met at the Griffin in Ancoats Lane and then moved to the Rifleman in New Market, where it sat daily to direct and supervise the collection and distribution of funds and the activities of the pickets and roving delegates. ${ }^{76}$

Apart from its shadowy role in organizing the pickets and processions, the standing committee coordinated two crucial and frequently interrelated aspects of the strike - fund raising and the delegate system. In addition to drawing on their friendly society funds and pawning personal belongings, the Manchester spinners also solicited money and credit from local shopkeepers and publicans and received contributions from other trades and from the spinners of surrounding towns and villages. Dennis Brophy, the landlord of the Rifleman, claimed that weavers, calico printers, fustian cutters, millwrights, foundry workers, tailors, and spinners from both the town and country had visited his house and had given money to the committee. ${ }^{77}$ During the opening weeks of the strike, the spinners had also authorized delegates to go out into the country. In addition to approaching the trades of local towns, like Bolton and Stalybridge, the delegates ranged even farther afield, visiting Liverpool, Chester, the Potteries, Sheffield, and Birmingham. ${ }^{78}$ In London the spinners managed to establish contact with the trades through the "revolutionary party" which was led by Dr. Watson, an impoverished surgeon and ally of Henry Hunt. Outside of young William Dugdale, a Stockport native, and John Hill, a journeyman tailor from Manchester, the spinners' main contact among the Watsonite radicals was a Lancashire man W. P. Washington. An active figure in Manchester radicalism, Washington had only recently moved to London and had kept up a correspondence with various parties in the north. In mid-July a man from Manchester, one of Washington's acquaintances, spoke to Watson's group about the spinners' struggle; several weeks later, on 12 August, Washington introduced the spinner delegates Swindells and Jones to Watson's committee and made arrangements for its members to distribute the spinners' circular among the London trades. ${ }^{79}$

${ }^{76} W M C, 14$ November; PRO, HO 42/179 Examinations of Dennis Brophy, John Ollis, Edward Johnson, and John Fowler, 29 August.

7 PRO, HO 42/178 Norris to Sidmouth, 29 July; HO 42/179 Norris to Hobhouse, 7 August; $M M, 1$ September, and HO 42/179 Examination of Dennis Brophy, 29 August. ${ }^{78}$ PRO, HO 42/179 Information of Samuel Fleming, 24 August; Information of Joseph Todd, 22 August; Examinations of Dennis Brophy and John Ollis, 29 August.

${ }^{79}$ PRO, HO 42/178 J. L. to Conant, 23 July; Report of C, 27 July; HO 42/179 Report of C, 10 and 24 August; Reports of A and C, 17 August; see also, Prothero, Artisans and 
As this circular clearly demonstrated, Swindells and Jones had journeyed to London not only to raise money for the spinners but also to encourage the trades of the metropolis to join "a Union of the operative Workmen, Mechanics, and Artizans of the United Kingdom". Watson's group was hardly the first to hear of this proposal for a general union of the trades. As early as July, spinner delegates had begun to spread this idea among the trades of local towns and had contacted in particular the colliers and weavers of the Oldham and Ashton districts. In late July and early August, when the weavers' grievances over low wages began to gather momentum, the creation of a general union was a topic of discussion at a series of weavers' meetings at Stockport, Ashton Moss, and Oldham. ${ }^{80}$ By late July the trades of the Manchester area had begun to hold delegate meetings to discuss the forming of "a general confederacy" of trades, and sometime in early August, probably around 10 August, these meetings led to the founding of what was called the "Philanthropic Society". ${ }^{81}$

A loose federation of local clubs, the Philanthropic Society grew out of the informal system of trade cooperation which had emerged in response to the spinners' struggle; the organizational similarities between the spinners' underground system and the general union, especially the common use of delegate meetings and rotating central committees, clearly pointed to the strike's role in the formation of the Philanthropic Society. But, it was also deeply rooted in the shared experiences and values of the spinners and the skilled trades. As the printed broadside announcing the formation of the society emphasized, the central grievance of the trades was "the Distressed State and Privations to which the Working Class of Society are reduced, by their avaricious Employers reducing wages to less than sufficient to support nature or purchase the bare necessaries for our existence". ${ }^{82}$ Of the fifteen trades that signed this broadside, eight took part in the strike wave of that summer, and in most cases, the striking trades had made similar complaints

Politics, pp. 100-101; Belchem, "Orator" Hunt, pp. 54-58, and Iain McCalman, Radical Underworld: Prophets, Revolutionaries, and Pornographers in London, 1795-1840 (Cambridge, 1988), p. 133.

${ }^{80}$ PRO, HO 42/179 Printed circular, 12 August, enclosed in Report of C, 17 August; see also, Prothero, Artisans and Politics, p. 100; "To all Colliers in Newton Duckinfield Hyde \& Stayley Bridge", from James Fielding, 7 August, enclosed in Lloyd to Hobhouse, 22 August; see also, Hammonds, Skilled Labourer, pp. 103-104; Hardman to Fletcher, 31 July; HO 42/178 Ramsay to Sidmouth, 18 July; HO 42/179 Brother to No. 2 to Chippendale, 27 July; XY to Byng, 3 August; Chippendale to Fletcher, 5 and 11 August.

${ }^{81}$ PRO, HO 42/179 Brother to No. 2 to Chippendale, 27 July and 10 August; Norris to Sidmouth, 5 August; Chippendale to Fletcher, 5 August.

82 PRO, HO 42/180 "At A Meeting of Deputies from the Undermentioned Trades", broadside. See also, Aspinall, Early English Trade Unions, pp. 272-274. Kirby and Musson, Voice of the People, p. 153. 
about the high cost of "the necessary articles of life" and about the reductions which their masters had made during 1815-17. By establishing a regional system of cooperation and mutual assistance, the Philanthropic Society provided the trades with a means of fighting the common problem of wage cutting competition among the masters and thus of establishing a standard price for labour throughout the Manchester area ${ }^{83}$ As the language of the broadside also suggested, the trades that joined the general union shared not only common problems but also a common outlook, that of the "respectable" artisan. Whether he was a journeyman spinner or an "industrious" hatter, the artisan believed that his skill gave him the right to a fair wage and a "respectable" status for himself and his family. "To the Labourers of Manchester and its Vicinity", a widely circulated address during the heady days of August, summed up the values behind "respectability": "That Labour being the Corner-stone upon which civilized society is built, no able, active Labourer, ought to be offered less for his labour, than will support the family of a sober and orderly man in decency, and credit." 84

As the spinners' role in promoting the general union and the timing of its founding suggested, the Philanthropic Society was very much a product of the dynamics of the spinners' struggle; it was related, above all, to the situation of the spinners' strike in late July and early August. "On Wednesday", the Chronicle reported, "a dead rabbit, stripped of skin and flesh, was hoisted on a lamp-iron in Deansgate, at the corner of the Shambles, with a placard underneath it, intimating that the spinners would be reduced to that condition before they would 'come in'." 85 This image vividly evoked not merely their determination and growing distress but also the state of the turn out-stalemate. Although the spinners had succeeded in closing almost all the mills in Manchester and in blocking an attempt in early August to reopen the factories, they had won only a few concessions by early August, mainly from a handful of small firms. By the end of the second week of August, the weekly division amounted to only nine pence. For many of the

${ }^{83}$ The eight trades were the dressers, dyers, handloom weavers, bricklayers, hatters, colliers, mule spinners, and jenny spinners. For complaints about high prices, see $M O$, 27 June (dyers), and 15 August (weavers). For the problems of establishing a standard list of prices, see $A$ Report of the Proceedings of a Delegate Meeting of Operative Spinners of England, Ireland, and Scotland (Manchester, 1829), pp. 6, 28-31; MO, 20 June (hatters), and Manchester Guardian, 25 September 1824 (shoemakers).

${ }^{84}$ PRO, HO 42/179 “To the Labourers of Manchester and its Vicinity", broadside. SPR, 8 August; Hammonds, Town Labourer, pp. 306-308; see also, British Library, Francis Place Papers, Additional Manuscripts 27799 vol XI, "Articles of the Philanthropic Hercules" and "Brother Mechanics". For "respectability", see Prothero, Artisans and Politics, pp. 26-28.

$85 W M C, 1$ August. 
spinners, their masters' object was clear; they intended, Johnson later charged, "to starve us out". 86

Amidst this atmosphere of tension and growing animosity, which the imminent prospect of strikes by the weavers and miners aggravated, a group of master spinners made a decisive move to break the deadlock. During the week of 23-29 August, they began to reopen their mills and simultaneously tried to break up the pickets by identifying and prosecuting their leaders. This decision was a direct challenge to the spinners, whose strike was dragging towards the close of its second unsuccessful month, and also marked a significant break with what Hobhouse had called "a lamentable apathy in the masters". This move by the master spinners and the ensuing violence in turn forced the Manchester magistrates to abandon their aloof attitude towards the strike and to take aggressive action to preserve the King's Peace. ${ }^{87}$ Partly as a result of this increased vigilance by the masters and the authorities, and partly as an attempt to overstretch the authorities' resources, the spinners adopted what Norris called a "guerilla mode of warfare", suddenly appearing at the mills at the opening and closing hours and then quickly dispersing. "The women", Norris observed, "(who are infinitely the worst) \& children are always put in front of the mobs the men keeping aloof - they make as you may suppose a considerable tumult in shouting \& the mob always takes care to get off before or the moment the military appear." 88 Apart from assaults on those returning to work and occasional clashes with the military and constables, several of whom were beaten and deprived of their "staves of office", the main objects of the spinners' abuse and threats were the master spinners. "Several most respectable gentlemen", noted one newspaper account, "employers in the spinning branch, have been surrounded in the streets, hooted, and grossly insulted by large mobs of women, boys, and men; chiefly, however, of the former." 89

By 1 September, when several hundred Manchester spinners attended the Stockport radicals' meeting in support of the striking trades, the spinners' turn out had already begun to break apart. During the past week, John Medcalfe, one of their delegates, had absconded with around $£ 150$ or £160; this had led to considerable dissension among the rank and file.

${ }^{86}$ PRO, HO 42/179 Norris to Sidmouth, 2 and 5 August; Norris to Hobhouse, 12 and 13 August; Hay to Hobhouse, 9 August; Examination of Edward Johnson, 29 August.

87 PRO, HO 42/179 Norris to Hobhouse, 26 August; Ethelston to Hobhouse, 28 August; Gray to Sidmouth, 24 August; Gray to Irving, 27 August. On 26 August the young Irish spinner John Doherty was arrested at Birley's mill. For the Home Office's growing impatience with both the Manchester mill owners and the magistrates, see HO 79/3 Hobhouse to Fletcher, 27 August; Hobhouse to Byng, 14 and 24 August; see also, HO $42 / 178$ Hay to Hobhouse, 30 July.

${ }^{88}$ PRO, HO 42/179 Norris to Hobhouse, 28 August.

89 WMC, 29 August. 
"Their Treasurer hath run away with about $£ 163$ ", reported one of Fletcher's spies, "which hath given their cause a shake as some of the shops had received their allowance and others remained unpaid which hath caused some uneasiness among them."90 Several days later the boroughreeve, deputy constable Nadin, and thirty odd officers and constables raided the Rifleman, in New Market, where they arrested the spinners' committee. Over the next few days, John Brough, "the Captain of the Pickets", and other leaders were also arrested. ${ }^{91}$

Deprived of their greatest strengths, leadership and organization, and weakened by internal dissension and the loss of their remaining funds, the spinners began to drift back to the mills, and in early September the strike collapsed amidst riot and violence. The bloodiest incident took place on 2 September at the Pollard street factory of Benjamin Gray, a vigorous opponent of the pickets and Manchester's largest employer of strikebreakers. ${ }^{92}$ While parading around Gray's mill, members of the crowd recognized his unpopular manager, James Frost, a former operative and one of the spinners' leaders during the 1810 strike, and immediately began to shout insults and threats. Frost quickly retreated into the mill, and a section of the crowd surged forward, pressing up against the doors and shouting "turn them out". At this point men on the roof began to throw stones, and the pickets responded with a fusillade of brickbats and tried to force their way into the factory. Several panic-stricken minutes later, men inside the mill opened fire, killing one young spinner and wounding about half a dozen. ${ }^{93}$ That evening the spinners returned, hooting and shouting threats against the troops and strikebreakers. After being pelted with stones, the soldiers fired into the crowd; one man fell to the ground. ${ }^{94}$

\section{III}

Although the spinners' struggle ended in defeat, the immediate effect of their strike was to create a general atmosphere of confrontation and militancy, especially among the handloom weavers. During the early weeks of their strike, spinner delegates had visited the weaving communities of

${ }^{90}$ PRO, HO 42/179 B to Fletcher, 31 August. Norris to Hobhouse, 26 August; Lloyd to Hobhouse, 29 August.

${ }_{91}$ PRO, HO 42/179 Norris to Hobhouse, 29 August; WMC, 5 September; Gorgon, 9 January 1819 , and HO $42 / 180$ Norris to Clive, 1 September.

${ }^{22}$ PRO, HO 42/179 Gray to Irving, 27 August; PP (Commons) 1824 [51] V, pp. 573-576.

93 Ibid., pp. 573-577; PRO, HO 42/180 Depositions of Jonathan Ambray and John Lever; Gray to Ethelston, 3 September; $M O$, 12 September, and $M G, 5$ September.

${ }_{94} W M C$ and $M G, 5$ September. 
Lancashire to solicit funds and later to spread the idea of a general union..$^{95}$ What ensured the spinner delegates a ready audience among the weavers was the low prices for weaving in 1818. During the previous three years, $1815-17$, the dramatic drop in piece rates, both for calico and muslin goods, forced many "industrious" weavers to turn to the parish for relief and led to accusations that some manufacturers had deliberately used the poor rates as a means of subsidizing low piece rates. ${ }^{96}$ In early 1818 , despite a modest revival in the cotton trade, wages in handloom weaving remained low. It was against this background of improving trade but continued low piece rates that a leading firm in Manchester announced a reduction of one pence per yard. This unpopular move touched off a storm of protest by the weavers and by a group of manufacturers who denounced the cut as unnecessary. Under pressure from these two groups, the firm withdrew the reduction and then promptly advanced prices by one pence a yard. This abrupt about-face reenforced the weavers' grievances about low wages and their suspicions about the masters' intentions and marked the beginning of local efforts to raise the prices of weaving. ${ }^{97}$ Writing in late June, a Prestwich weaver summed up the growing suspicions and anger of his fellow weavers. He blamed the low wages on the "ill will of our employers" and bitterly described the weavers' "state of unprecedented slavery" and their loss of status and "respectability": "We are considered [. . . ] as craftsmen or mechanics, and as such we consider ourselves; wherefore we naturally expect to obtain that reward for our labour which is sufficient to render our existence comfortable [. . .]. For our wages are so far from being upon a par with those of other mechanics, that it is now almost proverbial to say, 'any trade before weaving'.",98

In July and early August, when these grievances came to a head, the handloom weavers held a series of local meetings to publicize their plight and to discuss plans for an advance. Although the central concern of these meetings was the depressed state of the prices for weaving, the speakers raised not only the issue of an advance but also the question of reform and frequently spoke out in favor of a general union of all trades and a general strike, two common themes of meetings at Stockport, Oldham, and Ashton Moss. The most outspoken support for these measures frequently came from local radicals. At Oldham William Fitton and James Firth, both

95 PRO, HO 42/179 Hardman to Fletcher, 31 July; Chippendale to Fletcher, 5 August; Brother to No. 2 to Chippendale, 10 August; Hanley to Maule, 31 August.

* Bythell, Handloom Weavers, pp. 99, 102-105; MO, 11 July 1818 and 2 January 1819, and PRO, HO 42/174 Lloyd to Hobhouse, 23 February.

${ }^{77}$ Manchester Central Library, William Rowbottom diaries (microfilm copy), JanuaryMarch 1818; PP (Commons), 1824 [51] V, pp. 356-357; see also, Glen, Urban Workers, pp. 221-222.

${ }_{98} M O, 11$ July. See also, $M O, 2$ January 1819. 
well-known reformers, were militant advocates of "the Union of Trades". John Buckley likewise promised an Ashton Moss crowd, "One Generall union of all the Trades Will very soon be Effected and A Day fixed not far hence when all will Turn out in one Day". ${ }^{99}$ In the following weeks, as the weavers began to organize, the reformers continued to play an active role both as leaders of local committees and as delegates. Charles Walker, a delegate to the Hampden Club convention of January 1817, was elected secretary of the weavers' committee at Ashton-under-Lyne, an important center for the weaving of muslin goods and fine calicoes. Robert Pilkington of Bury, another veteran of the 1816-17 reform campaign, soon emerged as a leading advocate of the turn out at the weavers' delegate meetings and in early September marched through the streets of Bury and Bolton at the head of mass processions of striking weavers. ${ }^{100}$ By mid-August the radicals and their role in the movement had become controversial issues for the weavers. At meetings in Oldham and Stockport, where the crowds were clearly divided over these issues, radical speakers received a cool welcome from those who wished to limit the objectives to a wage increase. But, as Lloyd observed about Bagguley's reception at Stockport, the weavers who blocked his attempt to address the meeting met with vocal opposition from "a large party who were cheering him", and at Oldham the radicals" advocacy of the "the Union of Trades" had "many adherents". ${ }^{101}$ As late as the delegate meeting of 17 August, the weavers were still debating the question of reform. Chairman Ellison urged the delegates to avoid politics and stressed, "that must be the discourse of another day". Other delegates, however, argued that it was impossible to avoid politics, and a Stockport delegate called out that the people were ready. "They were not", he added, "going to make a Blanket job of it this time." 102 In certain small weaving villages, like Ashton-under-Lyne, where ties between the weavers and radicals were particularly close, the debate over the role of politics continued into September; but, even in Ashton, this debate reflected the divisions within the ranks of the weavers. Speaking in support of Charles Walker, who had condemned talk about an "open rebellion", "a very intelligent modest old man" warned an Ashton Moss crowd about the dangers of a premature uprising: "You may raise up 40 or 50 thousand men and when those are going to put their designs into practice perhaps one half might

99 PRO, HO 42/179 Brother to No. 2 to Chippendale, 27 July and 10 August. XY to Byng, 3 August; HO 42/178 Ramsay to Sidmouth, $18 \mathrm{July}$, and HO 42/179 Chippendale to Fletcher, 4 and 11 August.

100 Bamford, Passages, p. 9; PRO, HO 42/179 Brother to No. 2 to Chippendale, 10 August; HO 42/180 Chippendale to Sidmouth, 6 September.

101 PRO, HO 42/179 Lloyd to Hobhouse, 24 August; Glen, Urban Workers, pp. 221224, and HO 42/179 Chippendale to Fletcher, 11 August.

${ }^{102}$ PRO, HO 42/179 Information of Samuel Fleming, 18 August. 
desert the cause and other half get killed or get into some prison unless all was to rise up at once and be at in one mind." 103

In the wake of the initial round of local meetings in July, the weavers began to explore other courses of action and tried in particular to establish a regional system of organization and a common set of demands. Intense competition between master weavers, especially those of town and country, local variations in the piece rates, and the size and diverse composition of the work force placed the weavers in a difficult bargaining position and made some sort of regional organization a necessity. ${ }^{104}$ In an effort to overcome these obstacles, the weavers held a series of delegate meetings to work out a regionwide set of demands. On 22 July a group of weaver delegates gathered at an inn in Prestwich; several days later, on 27 July, weaver delegates from all parts of the cotton district met at Bury, where they settled upon a general advance in piece rates of seven shillings in the pound. Drawing on both the values and assumptions of political economy and popular notions of "respectability" and a "fair day's wage", the weavers' address first pointed to "our pre-eminence in the Commercial world" and the contrast between the prosperous state of trade and the low prices and long hours of weaving and then enlisted the weighty authority of Adam Smith, champion of the free market, to lend support to their demand for a just wage: "Smith says, 'A Labourer or Artizan should be able to maintain five', good God, but how must they exist on SIX SHILLINGS per week, which is the sum the greatest part of Weavers must work early and late to procure; not more than one-half the sum that is received by every other branch of the Trade." ${ }^{105}$ When the delegates returned to their districts with this demand, they received a variety of responses. Some manufacturers rejected the demand; others, like the Bolton masters, offered a smaller increase. At Ashton, Leigh, and Oldham the masters agreed to grant the full advance if the masters in other districts followed their example. ${ }^{106}$ After several weeks of unproductive negotiations on the local level and another round of delegate meetings, the thirty odd weaver delegates who met at Bury on 22 August issued an ultimatum - all weavers were to leave their looms on 1 September if their masters refused to grant the full advance. Once again, the weavers expropriated one of the celebrated figures of

${ }^{103}$ PRO, HO 42/180 Brother to No. 2 to Chippendale, 2 September. Cotton, "Popular Movements", pp. 113-116.

${ }_{104}$ Bythell, Handloom Weavers, pp. 96-98, 109, 169, 177-178; PP (Commons) 1834 [556] X, p. 73.

${ }_{105}$ PRO, HO 42/178 "An Address to the Cotton Manufacturers of Lancashire, Yorkshire, Cheshire, Derbyshire \&c.", broadside, 27 July. See also, Hammonds, Skilled Labourer, pp. 111-112; for the Prestwich meeting, see HO 42/178 Fletcher to Hobhouse, 26 July, and $P P$ (Commons) 1824 [51] V, p. 356.

${ }^{106}$ Hammonds, Skilled Labourer, pp. 112-115; Glen, Urban Workers, pp. 222-223, and Bythell, Handloom Weavers, p. 194. 
political economy to justify their demands. On this occasion, they used a quote from John Locke to support their claim that skill was a form of property:

Mr. Locke [. . . ] said that "every man that possesses his natural powers, has a property in himself, viz. in the work of his hands and the labour of his body." if so, we argue that they who by fraud or violence deprive the labourer of the fruits arising from his own property are Peculators, and if these are Peculators, those are Tyrants that would prevent him from taking the only commodity he has to the best Market. ${ }^{107}$

About a week before this climactic meeting of the weavers at Bury, the Oldham coal miners, who had been in contact with the spinners, issued a handbill convening a general meeting of their trade. In the address, "To All Coalminers", they reminded their fellow miners of the value of their labour:

The great bulk of Property in England is obtained by your Industry, (we dare venture to say, that there is not one manufactory in England but some part of it is in want of Coal) and look at the manufacturers and the Coal Dealers, how they get Riches for them and their Children, while you, the foundation of their wealth, are left in that State which will scarce keep the Soul and Body of you and your Children together. ${ }^{108}$

On the appointed day, 17 August, the colliers gathered "in vast numbers" at Kersal Moor and resolved to leave the pits unless the coal masters reduced hours and met the miners' demands about "prices and measure". ${ }^{109}$ When most of the coal masters rejected these demands, the miners turned out, probably on 24 August, about a week before the weavers' deadline. It was, like the weavers' turn out, a regional strike and involved not only the miners of Manchester and vicinity but also the miners of Ashton, Oldham, Bolton, and Stockport. ${ }^{110}$ During the course of the strike, the colliers

${ }^{107}$ PRO, HO 42/179 "At A Meeting of Deputies, From the Cotton Weavers", broadside, 22 August. Hardman to Fletcher, 22 August; see also, Hammonds, Skilled Labourer, pp. 114-115.

${ }_{108}$ PRO, HO 42/179 "To All Coalminers", handbill. For links between the spinners and miners, see HO 42/179 Norris to Hobhouse, 13 August; "To all Colliers in Newton Duckinfield Hyde and Stayley Bridge", from James Fielding, 7 August, enclosed in Lloyd to Hobhouse, 22 August; Hanley to Maule, 31 August.

${ }^{109}$ PRO, HO 42/179 Fletcher to Hobhouse, 18 August; Ethelston to Sidmouth, 18 August; Lloyd to Hobhouse, 22 August, and WMC, 22 August. For reductions over the previous two to three years, see Glen, Urban Workers, p. 104; J. R. Harris, "The Hughes Papers: Lancashire Social Life, 1780-1825", Transactions of the Historic Society of Lancashire and Cheshire, 103 (1952), pp. 122-126; HO 42/184 Hughes and Williams to the Earl of Derby, 17 February 1819. For grievances, see HO 42/179 No. 2 to Fletcher, 24 August; Norris to Hobhouse, 28 August ("the question of measure"); HO 42/180 Jones to Kinnersly, 1 September ("prices and measure"), and $M O, 4$ July (truck system).

${ }^{110}$ PRO, HO 42/179 XY to Fletcher, 26 August; Marriot to Hobhouse, 22 August; see 
adopted the familiar tactic of daily processions and coordinated the turn out through delegate meetings and a central committee sitting in Manchester. For the authorities, like William Chippendale, who closely watched the activities of "the notorious Dr. Healey" at Alkrington colliery, there was also concern about the role of the "Jacobins" in the turn out. ${ }^{111}$ But, with the exception of the Stockport miners, whose strike lasted into October, most of the colliers soon reached some sort of local agreement about prices and returned to the pits by mid-September. ${ }^{112}$

On Monday, 31 August, when the strikes of the coal miners and spinners had closed down most of the pits and mills of Manchester and its environs, thousands of weavers converged on Manchester, an act which heightened concerns about what Norris worriedly called "a simultaneous movement throughout the manufacturing district". This last round of negotiations took place throughout the towns and villages of Lancashire and Cheshire, from Blackburn in the north to Stockport in the southeast, and once again produced a mixed bag of offers. At Ashton-under-Lyne, where over four thousand had gathered in the town square, Charles Walker instructed the crowd to wait on their masters and demand the full advance. When the masters responded with the promise of a uniform two shillings increase, the weavers rejected it with contempt and gave a roar of approval to an offer by Bagguley, who "swore he would Lead up any Company Sword in hand". ${ }^{113}$ On Tuesday, 1 September, the principal market day in Manchester, thousands of men and women from the outlying weaving districts marched in regular military order through the city center, past the Police Office, "the Commercial Buildings", and the Manchester Exchange, "as if threatening defiance". ${ }^{114}$ Apart from demonstrating the weavers' mass support and attempting to overawe hostile masters and strikebreakers, the processions also dramatized the weavers' demands through the music of drums and fifes, the "imposing" display of banners and flags bearing the inscription "seven shillings or nothing", and the frequent use of the symbol of the reed and headle draped in black, an allusion to the well-known broadside "Death of Calico Jack". The Chronicle described one of these parades in

also, Glen, Urban Workers, p. 104, and Raymond Challinor, The Lancashire and Cheshire Miners (Newcastle, 1972), pp 23-24.

${ }_{111} M M, 8$ September; PRO, HO $42 / 180$ Jones to Kinnersly, 1 September; Fletcher to Clive, 4 September, and $\mathrm{HO} 42 / 179$ Chippendale to Hobhouse, 27 August.

${ }_{112} M M, 15$ September; WMC, 12 September; PRO, HO 42/180 Fletcher to Clive, 4 September; Fletcher to Sidmouth, 22 September, and HO 42/181 Lloyd to Clive, 10 October.

${ }^{113}$ PRO, HO 42/179 Norris to Clive, 31 August; HO 42/180 Norris to Clive, 1 September; Brother to No. 2 to Chippendale, 31 August, and Cotton, "Popular Movements", p. 115.

${ }_{114}$ Manchester Exchange Herald, 8 September, quoted by Bythell, Handloom Weavers, p. 194 , and $W M C, 5$ September. 
detail: "Another very large body of [ . . .] weavers, with many women, but with the imposing addition of being preceded by music and a pair of large colours, advanced into the town in military order from Stockport and that vicinity. They were headed by a man in a peculiar dress, bearing on his shoulders a reed and headle put into mourning by the symbol of a piece of crape attached to it."115 Despite the thousands who took part in these demonstrations, the processions remained peaceful; some of the weavers' other tactics, however, led to sporadic outbursts of violence. There were scattered accounts of striking weavers gathering shuttles and throwing vitrol on the warps of those who were at work, and on Saturday Norris reported widespread attempts to obstruct country weavers on their "bearing home day". At Stockport the weavers, like the Wigan spinners, turned to the anonymous threatening letter as a way of coercing and intimidating unpopular masters. ${ }^{116}$

On 5 September, when forty odd weavers met at the Spread Eagle in Bury to review the events of the past week, the delegates, like their fellow weavers, were sharply divided over strategy and goals and were also deeply concerned about the threat of official repression. What occurred on that evening was "a struggle of uncommon severity for several hours". A handful of delegates led by the radical Robert Pilkington argued in favor of continuing the strike for the full advance of seven shillings; the chairman Ellison and the main body of the delegates, however, opposed this measure and instead passed two cautiously worded resolutions calling on the weavers to accept the advance in installments, four shillings on 7 September and three shillings on 1 October, but to refuse to work for below these prices. ${ }^{117}$ This decision, together with the lure of the promised advances from local manufacturers, led to a drift back to the looms; it also resulted in the issuing of warrants on 16 September for the arrest of several key leaders, like Pilkington and Ellison, on charges of conspiracy. By this point most of the weaving communities in south Lancashire and adjoining areas had already returned to work, with the exception of Bolton and neighbourhood, where some of the weavers refused to return to work. ${ }^{118}$

115 WMC, 5 September. PRO, HO 42/180 Brother to No. 2 to Chippendale, 1 September; Norris to Clive, 2 and 3 September; for the broadside "Death of Calico Jack; or the Weavers' Downfall”, see Glen, Urban Workers, pp. 146, 154, 195, 214, 223.

${ }^{116}$ PRO, HO 42/180 Norris to Clive, 1 September; Norris to Sidmouth, 5 September; Ethelston to Sidmouth, 7 September; PP (Commons) 1824 [51] V, p. 360; HO 42/180 Lloyd to the Undersecretary of State, 19 September, and HO 42/179 Lyon to Freeling, 24 August.

${ }^{117}$ PRO, HO 42/180 Chippendale to Sidmouth, 6 September; PP (Commons) 1824 [51] V, pp. 394-395; see also, Glen, Urban Workers, p. 223, and Hammonds, Skilled Labourer, pp. 116-117.

${ }_{118}$ PRO, HO 42/180 Norris to Sidmouth, 11 September; Fletcher to Clive, 4 September; $W M C, 12$ September; for the arrest of the weavers' leaders, see HO $42 / 180$ Norris to 
In north Lancashire, especially in the extensive calico weaving districts around Blackburn and Burnley, the strike lasted into late September, and it was in these isolated towns and villages that the weavers' strike took on its most violent form. "The Hundred of Blackburn", wrote magistrate Whitaker, "is in a State approaching to that of a general insurrection [. . .]. The Houses of the Weavers who are willing to work are visited their looms \& work marked and themselves inhibited from proceeding by Threats of Fire or other Mischief." 119 The weavers' practice of marching "in procession through the Public Streets", the High Sheriff charged, likewise contributed to unrest in the Blackburn division, and in mid-September, there were riots in the outlying villages. At Burnley several hundred weavers stormed the lock up house and freed one of their arrested leaders; at neighbouring Padiham a crowd threw stones at a troop of dragoons who were conveying arrested weavers to Preston. ${ }^{120}$

In late September, at a series of meetings in Preston, the handloom weavers turned to the more subtle methods of inversion and parody to criticize their employers and to dramatize the plight of their trade. The first of these "singular measures" involved the use of a green bag, an allusion to the 1812 and 1817 Committees of Secrecy and the infamous "green bags" of evidence. ${ }^{121}$ That summer the Preston weavers used the device of the green bag as a means of evoking memories of the Tory government's repressive measures against the Luddites and the radicals and as a way of stigmatizing an unpopular master. The slip of paper which the weavers drew from the bag bore the name of one of Preston's most politically powerful and wealthiest families, and by drawing the name of Horrocks, Miller, and Co., the weavers forcefully expressed their "spirit of hostility" towards the Horrocks family, a bastion of local Toryism and a staunch opponent of the advance. ${ }^{122}$ A letter from Preston described this incident in detail:

Sidmouth, 7, 11, 12, and 16 September; Fletcher to Sidmouth, 22 September, and The Times, 17 September.

${ }^{119}$ PRO, HO 42/180 Whitaker to Sidmouth, 17 September. Bythell, Handloom Weavers, pp. 28-29, 196.

${ }_{120}$ PRO, HO 42/180 "The Town and Neighbourhood of Blackburn", broadside, 11 September; The Times, 21 September; $M M, 22$ September, and $W M C, 19$ and 26 September.

121 "The History and Mystery of the Green Bags", Town Talk; or Living Manners, 3 (1812), pp. 1-6; Henry Hunt, The Green Bag Plot (London, 1819), and M. Dorothy George, English Political Caricature 1793-1832: A Study of Opinion and Propaganda (Oxford, 1959), pp. 174-175. I am grateful to Harold Moser for the reference to Town Talk. For the use of "green bags" in the Queen Caroline affair, see the dialect poem "Jone O' Greenfeelt's Ramble in Search of th'Green Bag", in John Harland (ed.), Ballads and Songs of Lancashire, Ancient and Modern, revised by T. T. Wilkinson (second edition, London, 1875), pp. 172-173, and McCalman, Radical Underworld, p. 174.

${ }_{122}$ John Horrocks was M.P. for Preston, 1802-04. His elder brother Samuel Horrocks 
A full meeting of their body was held yesterday [. . .] at which a green bag was produced and the names of the manufacturers of that district being written on slips of paper were put into it. A resolution was then put, and carried unanimous$l y$, that the first name drawn from the bag should be read out of the trade, and that no weaver should be allowed to work for him. The first name drawn proved to be the firm of Horrocks, Miller, and Co., and produced loud applause from all present. It was put to the vote, and carried by a show of hands, that no weaver should work for that firm. ${ }^{123}$

The next week the Preston weavers turned upside down the solemn conventions of the funeral procession and shifted the central focus of the ceremony to the death of the trade of weaving. After assembling at the top of High Street, their usual meeting place, and passing several resolutions, the weavers "proceeded in sham funeral procession to Gallows Hill, where a grave being made, one of their leaders pronounced an oration, and a set of weavers' gearings were deposited in the ground". ${ }^{124}$

\section{IV}

The "sham funeral procession" of the Preston weavers, with its obvious references to the death of their trade, itself both a creation and casualty of the first wave of industrialization, serves as a dramatic reminder that the 1818 strikes took place at a time of transition from the world of the loomshop and the putting out system to the world of the factory and steam engine. In 1818 these two worlds, both the old and the new, still existed side by side, even in the spinning rooms, collieries, and weaving sheds of the cotton district, and the attitudes and actions of the thousands of men and women who turned out that summer partook of both worlds. Although the addresses of the striking trades frequently presented the case for an ad-

served as M.P. for the borough, 1804-26. One of the founding families of the cotton industry in Preston, the Horrocks employed in 1816 hundreds of factory workers and "a whole countryside of handloom weavers", Gentleman's Magazine (1842), p. 430; Edward Baines, History, Directory, and Gazetteer, of the County Palatine of Lancaster, 2 vols (Liverpool, 1824-25; reprint edition, New York, 1968), 2, pp. 484-485; Paul T. Phillips The Sectarian Spirit: Sectarianism, Society, and Politics in Victorian Cotton Towns (Toronto, 1982), pp. 39, 64; Patrick Joyce, Work, Society, and Politics: The Culture of the Factory in later Victorian England (New Brunswick, NJ, 1980), p. 13, and Bythell, Handloom Weavers, p. 30.

${ }^{123}$ The Times, 28 September. For other accounts, see $W M C, 10$ October, and $M M, 29$ September.

${ }^{124} W M C, 10$ October. See also, $M M, 6$ October; $M O, 10$ October; for the military "sham funeral" in nineteenth-century Philadelphia, see Davis, Parades and Power, pp. 66-67; for the mock burial of the "shift system" by a group of Stalybridge weavers, see The Champion, vol. 2, no. 18. 
vance in classic market terms, with references to the prosperity of trade and commerce and the "state of the market", the addresses almost always linked the wage issue to the idea of a "fair day's wage" and the artisan's loss of "respectability" and status, a set of grievances which had little to do with the values of political economy and the market. In two of their addresses the handloom weavers even turned to Adam Smith, champion of the free market, to lend support to their call for a just wage and likewise used John Locke to brand the master manufacturers as "Peculators" and "Tyrants". This kind of allusion to "tyranny" and "despotism" in the work place was hardly unique. Throughout the summer criticism of the "tyrannical" power of the masters vied with appeals to what a group of Oldham weavers called the "persevering attachment of the manufacturers and weavers to each other's interest". ${ }^{125}$ Just as the attitudes of the men and women who turned out that summer were imbued with this sense of tension between old, paternalistic notions about reciprocal obligations and a growing hostility towards "the overgrown capitalists", the actions of the striking trades exhibited a similar tension between old and new forms of action and between violent and constitutional protest. A mixture of what Charles Tilly has called "communal" and "associational" forms of solidarity, this repertoire included not only the charivari and the anonymous letter but also the "constitutional" meeting, the picket, and the "imposing" display and symbolism of the mass procession. ${ }^{126}$

Partly a product of industrialization and its impact on social relations in Manchester, and partly a consequence of the related decline of the "moral economy" and "the politics of food riot", these changes in the repertoire of working-class protest in early nineteenth-century Lancashire also reflected the growing influence of the radicals and their emphasis on open, constitutional agitation. ${ }^{127}$ By rallying to the side of the trades in 1818 , the radicals strengthened their ties to the working men and women of the cotton district and forcefully identified the cause of reform with the working class. Throughout the long, hot summer, the local leaders of the reform movement and the radical press supported the demands of the striking weavers and journeymen and vigorously attacked the "tyranny" of the master manufacturers and mill owners; "the people's champion" Henry Hunt, the foremost national leader of the movement, likewise defended the spinners' strike and the right of the "industrious labourer" to a fair wage. In small

${ }^{125}$ PRO, HO 42/178 "To the Gentlemen, Landholders, and Ley payers of Oldham \& its Vicinity", handbill, 25 July; see also, Aspinall, Early English Trade Unions, pp. $249-250$.

${ }_{126}$ Charles Tilly, "Collective Violence in European Perspective", in H. D. Graham and T. R. Gurr (eds), Violence in America: Historical and Comparative Perspectives (revised edition, Beverly Hills, CA, 1979), pp. 107-109.

${ }^{127}$ Bohstedt, Riots and Community Politics, pp. 84-99. 
weaving communities, like Ashton-under-Lyne, where the ties between the radicals and the weavers were particularly close, radicals raised the call for a general strike and "the Union of Trades" and served as leaders of weavers' committees and as delegates during the handloom weavers' turn out. In early September, near the climax of the "simultaneous movement" in the cotton district, the veteran reformers Bagguley, Drummond, Johnston, and Pilkington were arrested for their involvement in the strikes.

Just as the relationship between the radicals and the striking trades affected the events of that summer, the trade militancy of that summer in turn shaped and influenced the revival of the mass platform in early 1819 and made Manchester and vicinity the center of the radical campaign. In the course of their two-and-a-half-month strike, the Manchester spinners had turned to the London trades and the ultra-radical followers of Dr. Watson for support, and over the next few months, spinner delegates continued to visit the metropolis and on occasion served as intermediaries between certain Manchester radicals, like James Wroe, and Watson's circle. By early 1819, Watson's subscription scheme, his "Universal Union Fund of the Non-Represented People", enjoyed considerable support in the Manchester area, where twenty to thirty sections had been formed. ${ }^{128}$ The 1818 strikes also marked the entry of Rev. Joseph Harrison, a friend of Bagguley and an "usher" at his Stockport school, into radical politics and contributed to the founding of the Stockport Union for the Promotion of Human Happiness, one of the largest and most active reform societies in the manufacturing districts in 1819. In the wake of the strike wave's collapse, Rev. Harrison and a group of reformers launched a campaign to publicize the plight of Bagguley, Drummond, and Johnston. ${ }^{129}$ This campaign succeeded in setting up a national subscription for the Chester prisoners and made the arrest and prosecution of the radical martyrs and the trade union leaders an important rallying point for the radicals not only in the cotton district but also on the national level. In addition to the towns and villages of the Manchester and Stockport area, Glasgow, Hull, Liverpool, Macclesfield, Nottingham, and Birmingham all contributed to the subscription fund for the defense of the three radicals; in London several members of Watson's circle, in particular W. P. Washington and John Gast, the shipwrights' leader, took up the cause of the arrested spinners. ${ }^{130}$ In early December the

${ }^{128}$ PRO, HO 42/181 Hanley to Maule, 12 October; Report of C, 12 October; Gorgon, 9 January 1819; see also, Prothero, Artisans and Politics, pp. 100, 106-107, and Belchem, "Orator" Hunt, pp. 87-88.

129 PRO, HO 42/179 Ramsay to Lloyd, 10 August; Norris to Hobhouse, 11 August; HO 42/180 Report of John Livesey; Glen, Urban Workers, pp. 224-236; see also, Read, Peterloo, pp. 38, 47-49.

${ }^{130}$ Glen, Urban Workers, pp. 224-225; A Full, Accurate, and Impartial Report, pp. 6364; PRO, HO 42/181 Hanley to Maule, 12 October; British Library, Francis Place 
wealthy reformer Sir Charles Wolseley, one of the founders of the Hampden club, visited Stockport and offered to post bail for the three men. Several weeks later, on the eve of the first great Manchester demonstration, Henry Hunt met with the Stockport radicals and discussed the upcoming trial of the radical martyrs. ${ }^{131}$ At the mass meetings of 1819 , the radicals continued their attack on the arrest of the "noble patriots" and on "partial and unjust laws" and condemned the imprisonment of the trade union leaders as an example of the inequities of the Combination Acts, a common theme of the speeches and resolutions of that year. ${ }^{132}$ "This is the effect", charged William Fitton about the arrest of the weavers' leaders, "of the protecting laws of the rich against the fair and honest claims of the poor." 133

Papers, Additional Manuscripts 27799 vol. XI, "The Appeal of W. P. Washington", handbill, 31 July 1819. Prothero, Artisans and Politics, pp. 101-102. James Wroe, a radical bookseller and later editor of the Manchester Observer, was one of the sureties for John Doherty's bail and received subscriptions for the defense of the arrested spinners; see, Kirby and Musson, Voice of the People, pp. 22, 45.

131 Glen, Urban Workers, p. 226, and MO, 23 January 1819.

${ }^{132}$ MO, 23 January 1819 (Manchester); 13 and 20 February 1819 (Royton and Stockport); 19 June 1819 (Ashton); 3 July 1819 (Stockport); 10 July 1819 (Blackburn); see also, Hammonds, Skilled Labourer, p. 120.

${ }^{133} M O, 20$ February 1819 . For radical dinners to celebrate the release of the imprisoned radicals and trade union leaders in 1821, see $M O, 10$ February, 3 March, 28 April, 26 May, and 23 June. 